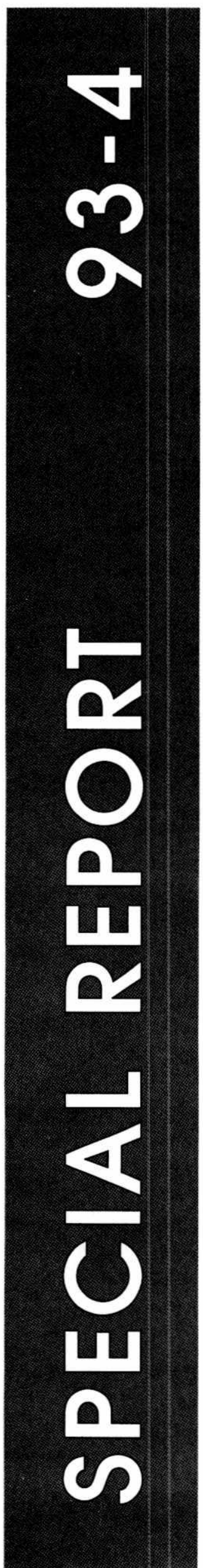

\title{
Icing of Turbine Intake Louvers
}

Michael R. Walsh, Donald E. Garfield, James S. Morse,

Kurt V. Knuth, Nathan D. Mulherin and George E. Lemieux 


\begin{abstract}
Superstructure icing can have debilitating effects on the operation of any ship. When designing ships that will operate in environments where icing may occur, careful consideration must be given to minimizing the accumulation and effect of shipboard icing. Such consideration was given to the Navy DDG-51 class destroyer when new turbine intake louvers were proposed. To ensure that sufficient air would be available to the vessel's gas turbines and ventilation system during an icing event, the U.S. Navy tasked the U.S. Army Cold Regions Research and Engineering Laboratory (CRREL) to conduct a series of comparative icing tests between standard intake louvers and a new louver design. Using a test matrix and design parameters supplied by a Navy contractor, CRREL designed a test apparatus and instrumentation suite to carry out the tests. Testing conducted with reconstituted seawater at the CRREL facility demonstrated that, under various icing conditions, the rate of ice accumulation of the two louver designs was very similar. However, the increased number of louver vanes of the proposed design led to more rapid restriction of air accumulation on the vanes.
\end{abstract}

For conversion of SI metric units to U.S./British customary units of measurement consult ASTM Standard E380-89a, Standard Practice for Use of the International System of Units, published by the American Society for Testing and Materials, 1916 Race St., Philadelphia, Pa. 19103.

This report is printed on paper that contains a minimum of $50 \%$ recycled material. 


\section{Special Report 93-4}

\section{US Army Corps \\ of Engineers}

Cold Regions Research \& Engineering Laboratory

\section{Icing of Turbine Intake Louvers}

Michael R. Walsh, Donald E. Garfield, James S. Morse,

Kurt V. Knuth, Nathan D. Mulherin and George E. Lemieux 


\section{PREFACE}

This report was prepared by Michael R. Walsh, Mechanical Engineer; Donald E. Garfield, Supervisory Mechanical Engineer; James S. Morse and Kurt V. Knuth, Electronics Engineers, Engineering Resources Branch, Technical Resources Center; and Nathan D. Mulherin, Research Physical Scientist; and George E. Lemieux, Research Physicist, Snow and Ice Branch, Research Division, U.S. Army Cold Regions Research and Engineering Laboratory, Hanover, New Hampshire (CRREL). Funding for this work was provided by Advanced Marine Enterprises, Inc. (AME), of Arlington, Virginia, through a Cooperative Research and Development Agreement between CRREL and AME. LCDR Paul D. Longo, U.S. Navy Liaison Officer, and Walter Tucker, both of CRREL, reviewed this report.

The contents of this report are not to be used for advertising or promotional purposes. Citation of brand names does not constitute an official endorsement or approval of the use of such commercial products. 


\section{CONTENTS}

Page

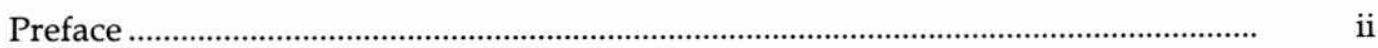

Facilities and instrumentation .................................................................................

Pre-test investigations ...................................................................................................

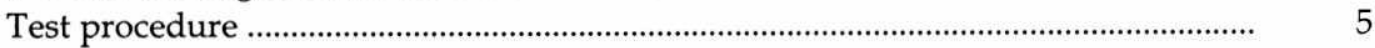

Results and analyse .............................................................................................

Droplet size distribution ..........................................................................................

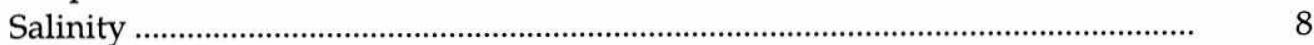

Sea spray ice density ............................................................................................ 8

Louver icing distribution and rate ........................................................................... 8

Conclusion ............................................................................................................... 9

Appendix A: Spray droplet size distribution data .................................................... 11

Appendix B: Salinity measurement procedure ............................................................. 13

Appendix C: Louver ice thickness data …………....................................................... 19

Appendix D: Analysis of louver ice samples for density ........................................... 35

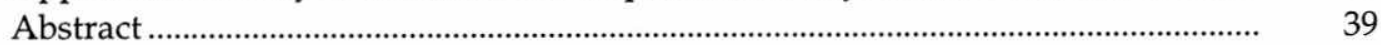

\section{ILLUSTRATIONS}

Figure

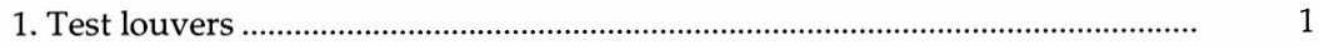

2. Test setup …................................................................................................. 2

3. Intake unit ......................................................................................................

4. Iced propeller anemometer .................................................................................. 3

5. Air velocities in front of the 100-series louver .................................................... 5

6. Icing thickness measurement nomenclature ......................................................

7. Droplet analysis results .......................................................................................... 8

8. Average ice accretion rates .................................................................................. 9

\section{TABLES}

Table

1. Test matrix developed by AME ......................................................................... 5

2. Standard test procedure ..................................................................................... 6

3. Mean and range of salinity measurements for each test. .................................. 8

4. Summary of ice density data ................................................................................. 


\title{
Icing of Turbine Intake Louvers
}

\author{
MICHAEL R. WALSH, DONALD E. GARFIELD, JAMES S. MORSE, \\ KURT V. KNUTH, NATHAN D. MULHERIN AND GEORGE E. LEMIEUX
}

Superstructure icing is a phenomenon that can have debilitating effects on the operation of any ship. When designing ships that will operate in environments where icing may occur, careful consideration must be given to minimizing the accumulation and effect of superstructure icing. Such consideration was given to the U.S. Navy DDG-51class destroyer when new turbine intake louvers were proposed. To ensure that sufficient air would be available to the vessel's gas turbines and ventilation system during an icing event, the Navy asked the U.S. Army Cold Regions Research and Engineering Laboratory (CRREL), through Advanced Marine Enterprises, Inc., (AME) of Arlington, Virginia, to conduct a series of comparative icing tests between standard intake louvers and a new louver design.

Advanced Marine, Inc., designed a test matrix and established testing parameters. Using this information, we designed a test apparatus and instrumentation suite to carry out the tests. The CRREL low-temperature seawater facility (the cold pit) was used to test the intake louvers. This report describes the test apparatus and instrumentation, the test procedure, the data obtained from the tests and the results.

\section{FACILITIES AND INSTRUMENTATION}

The facility chosen for testing the louver models was the CRREL cold pit, a 6.7-×7-m coldroom used for seawater and saline ice investigations. This room has an overall height of $6.4 \mathrm{~m}$ with an open grid floor at the 3-m level accessible through a set of large swinging doors ( $3 \mathrm{~m}$ wide by $1.9 \mathrm{~m}$ high) that open into a staging area in the main lab. The coldpit temperature can be controlled down to $-23^{\circ} \mathrm{C}$, while the staging-area temperature is maintained at $20^{\circ} \mathrm{C}$. A one-ton-capacity overhead crane is located above the grid floor. The power available in the cold pit includes single-phase $115 \mathrm{VAC}$ and three-phase $230 \mathrm{VAC}$.

The intake louver models tested at CRREL are representative sections of actual louvers being considered for use with the DDG-51-class U.S. Navy destroyer. The frontal area of the test louvers is approximately $35 \%$ of an actual louver, while the model louver vanes are full size (Fig. 1). The louver vane material was quarter-inch $(6.35-\mathrm{mm})$ steel. In both models the long axis of the vanes was vertical. The significant difference between the two test louvers was that the model of the proposed louver had vanes with $110^{\circ}$ bend. The standard louver configuration had vanes oriented $45^{\circ}$ to the airflow. A second difference between the designs was the number of vanes; the prototype louver had

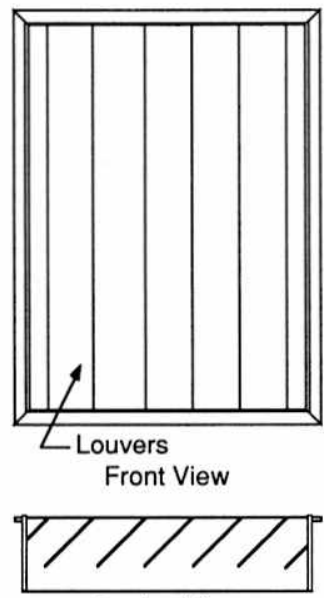

Section View a. Original (100series) louver.
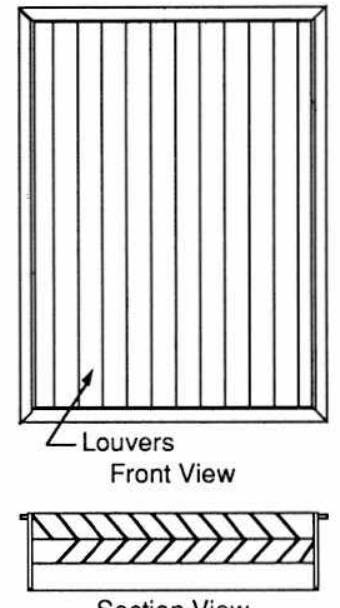

Section View

b. Prototype (200series) louver.
Figure 1. Test louvers. 


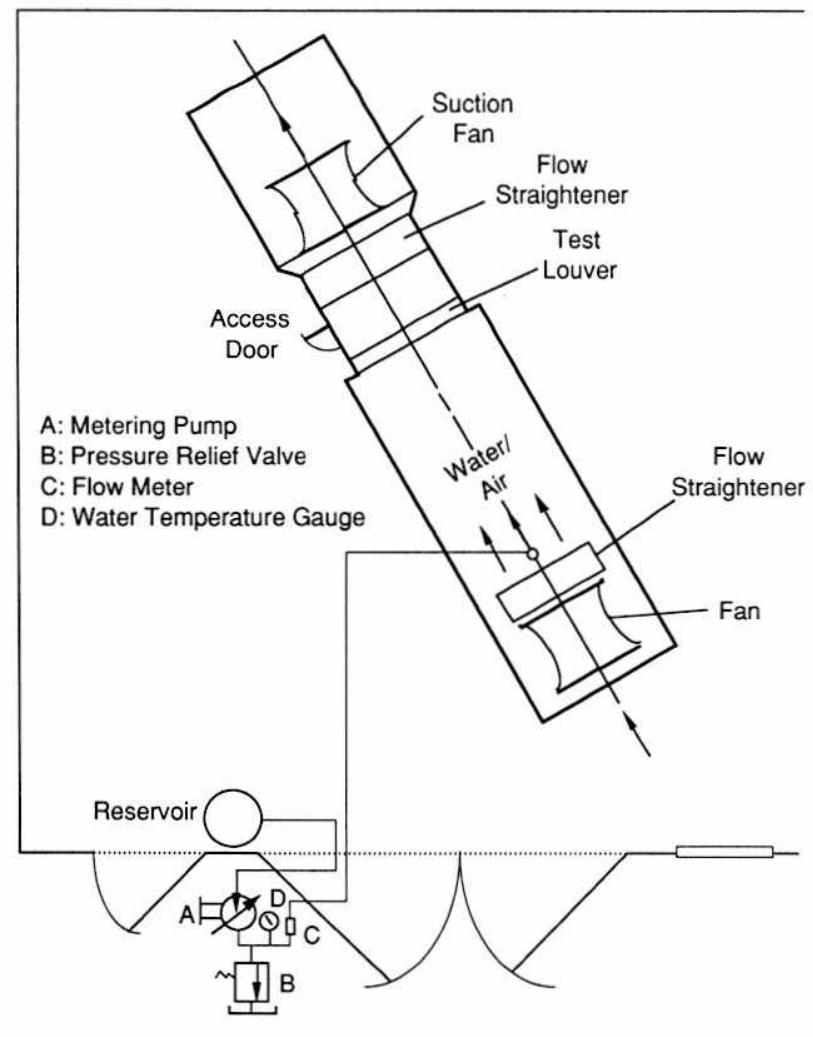

a. Plan view. intake unit and the instrumentation suite. The blower unit consisted of an adjustable-vane axial fan with a capacity of $4.48 \mathrm{~m}^{3} / \mathrm{s}$. The fan's diameter was $610 \mathrm{~mm}$. The blower fan exhausted into a 0.8-m-square flow straightener composed of stacked $10-\mathrm{cm}$-diam. by $0.96-\mathrm{m}$-long PVC drain pipes with a small-mesh screen diffuser on the front. The air velocity and volume were varied for the tests by adjusting the vanes on the blower. The air velocity $3 \mathrm{~m}$ from the front of the blower varied from 3.4 to $8.5 \mathrm{~m} / \mathrm{s}$, depending on the vane setting.

The spray assembly was composed of a spraygenerating system with associated controls and instrumentation. The fluid supply consisted of a 208-L heated and insulated barrel of reconstituted seawater located inside the cold pit. A thermostatically controlled heater maintained the water temperature just above freezing. From the barrel, the seawater was pumped through flexible nylon (Tygon) tubing to a series of spray nozzles mounted on a stand in front of the blower unit. The water temperature at the nozzles was monitored with thermocouples. The nozzle water temperature was regulated by varying the amount of hose that was exposed in the staging area, where the pump was located. The nozzles were 0.43 -and 0.61 -mm-orifice spray nozzles with a $75^{\circ}$ angle of deflection. AME chose these nozzles from a number tested by CRREL. Because the nozzle orifices were so small, the water was filtered before being pumped to the sprayers.

The pump used in the spray system was a $0.084-$ $\mathrm{mL} /$ revolution magnetically coupled, variable-speed gear pump. The maximum flow rate at $140 \mathrm{kPa}$ was 580 $\mathrm{mL} / \mathrm{min}$. The operating temperature range was -46 to $121^{\circ} \mathrm{C}$. The pump speed was regulated with a 2 - to 24 -VDC power supply and speed controller. The top speed of the motor was $8000 \mathrm{rpm}$. Two glass-fiber filters were placed in parallel in front of the pump. If the filters began to clog before the end of a test, one filter line could be pinched off and the filter material changed. The process would then be repeated for the second filter, thus ensuring continuous operation of the spray system. A small cabinet fan was used to cool the pump motor, as it was not 


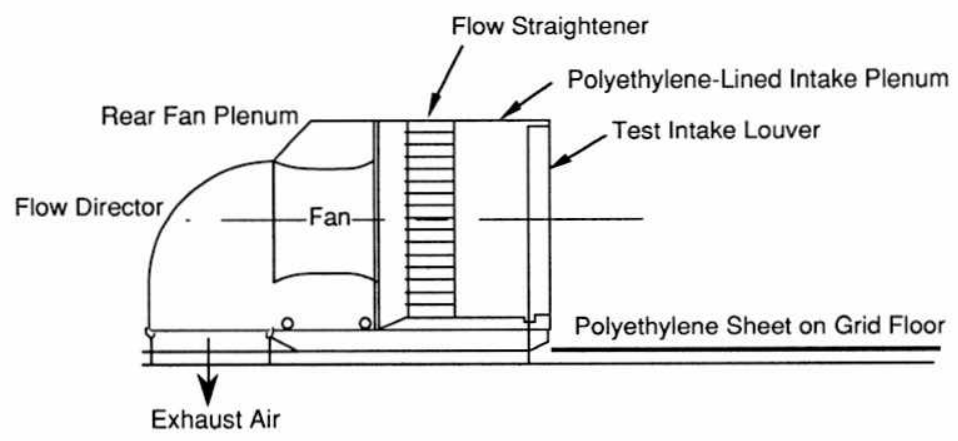

Figure 3. Intake unit.

rated for continuous duty. A pressure gauge and a pressure relief valve were installed downstream from the pump to monitor the water pressure (in case the line broke) and to protect the pump and motor (in case the line froze).

The intake unit consisted of three basic parts (Fig. 3). In the front, an open-ended polyethylenelined frame was constructed to accept the louver models. This was $1.2 \mathrm{~m}$ wide $\times 1.3 \mathrm{~m}$ high $\times 0.9 \mathrm{~m}$ deep. It attached to the rear fan plenum, which was $0.9 \mathrm{~m}$ wide $\times 1.25 \mathrm{~m}$ high $\times 1.2 \mathrm{~m}$ long. The rear plenum was $14 \mathrm{~cm}$ higher than the front adapter to ensure that the suction fan would be located along the central axis of the louver. Located in the rear plenum between the fan and the adapter was a flow straightener similar to that for the blower unit. The suction fan was also similar to that in the blower unit except larger. It had a capacity of $8.02 \mathrm{~m}^{3} / \mathrm{s}$ with 3-m air velocities of 6.5-11.4 m/s, depending on the vane setting. The fan's diameter was 762 $\mathrm{mm}$. The motor was a $230-\mathrm{V}$ three-phase explosion-proof model sealed against infiltration from the saltwater mist in the airstream. A flow direction changer was mounted on the exhaust end of the rear plenum to direct the system exhaust below the grid floor, thus minimizing air turbulence in the test zone. A sheet of polyethylene was laid on the floor between the spray and intake assemblies to further reduce cross-flow interference. The distance between the blower and intake units was approximately $2.5 \mathrm{~m}$.

Due to the short time allowed to prepare for testing of the louvers, a fully integrated instrumentation suite could not be assembled. Thus, while some test variables could be monitored with a data acquisition system (DAS), others had to be measured and recorded by hand. Temperature, relative humidity and seawater flow rate to the nozzles were all recorded using a DAS, while at one-hour intervals we manually recorded ice thickness, airspeed and pressure differential, and we took samples for measuring louver runoff salinity, ice density and droplet size. Instrumentation designed to collect airspeed data through the DAS proved inadequate due to icing problems (Fig. 4).

Automated data collection was performed by a Campbell CR-10 DAS connected to a multiplexer and memory module. Data were collected at 5minute intervals. Temperature sensors were type$\mathrm{T}$ (copper-constantan) thermocouples that had waterproofed sensing junctions. Thermocouples

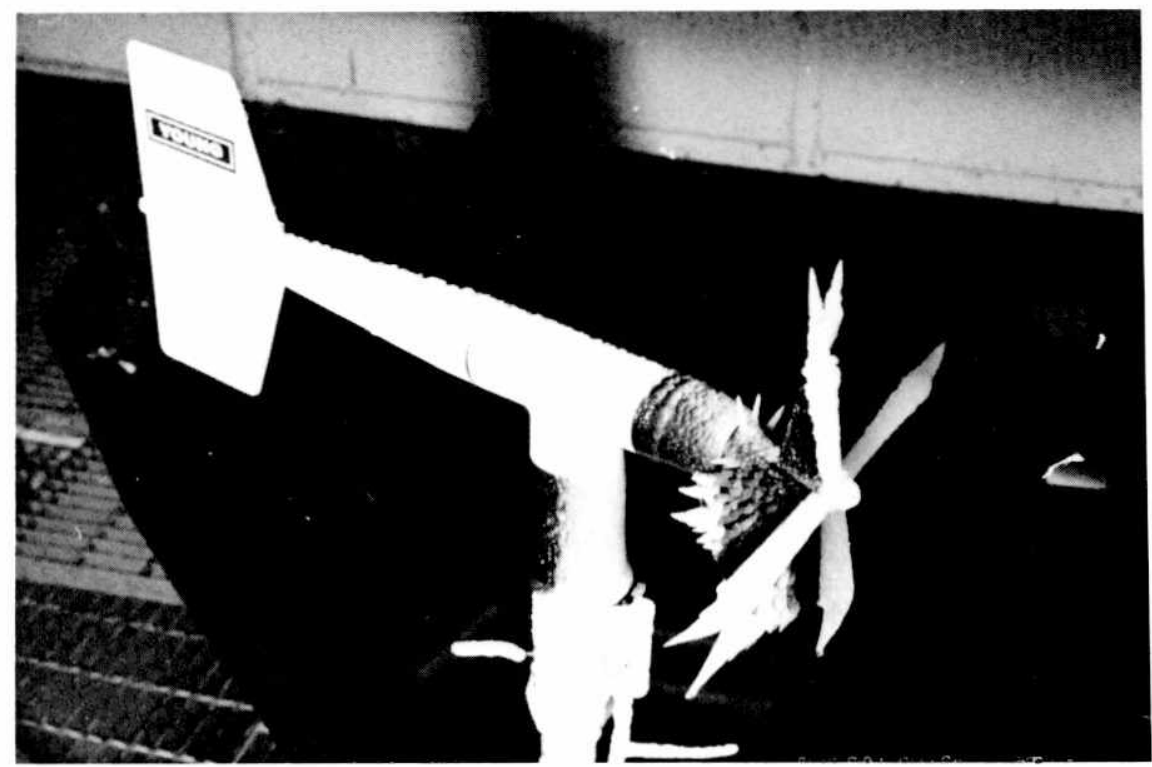

Figure 4. Iced propeller anemometer. 
were made using the direct-pressure, quick-tip method. The water flow rate was monitored with a McMillan model 111-5 flowmeter, which, in addition to a 0 - to 5-VDC analog output signal, had a small LCD readout, which allowed visual monitoring of the flow rate during tests. The analog output signal was passed through a 2:1 voltage divider and was directly proportional to the flow rate, which ranged from 50 to $500 \mathrm{~mL} / \mathrm{min}$. Relative humidity was monitored using a chilled-mirror RH meter, which failed due to icing, and an Omega modelHHF-710thin-film capacitive-type $\mathrm{RH}$ probe. Two automated wind velocity sensors were tried without success. The first, an R.M. Young propeller anemometer, quickly iced up. The second, a hotwire anemometer, burned out due to icing. Thus, a hand-held three-cup anemometer was used to obtain air speeds manually. Airspeeds were recorded before each series of measurements.

Ice thicknesses on the louvers were measured using vernier calipers at one-hour intervals and were recorded manually. Runoff brine samples were also collected at one-hour intervals in $20-\mathrm{mL}$ scintillation vials for later analysis in the CRREL water quality lab. The differential pressure across the louver was measured using a U-tube manometer. The manometer, filled with green-dyed water for ease of reading, was located outside the cold pit to prevent freeze-up. One manometer end was located in still air in the pit and the other behind the center of the test louver. Readings were taken off a machinist's rule between the two water columns. Samples of the water droplet size distribution were taken at the beginning of each test using the silicone oiled-slide method for later analysis. Ice density samples were taken at the end of each test.

\section{PRE-TEST INVESTIGATIONS}

Before any testing of the louvers could begin, a procedure for reconstituting the seawater to be used in the tests had to be established. The reconstituting was performed in a 208-L (55-gal.) drum. The drum was filled with tap water, $7 \mathrm{~L}$ of water was removed, $6.8 \mathrm{~L}$ of Morton "Purex all-purpose" salt was added to the drum, and a stirrer was installed. The drum and stirrer were the placed in a coldroom $\left(0^{\circ} \mathrm{C}\right)$ while stirring continued. After 8 hours the solution was checked with a salinity meter and adjusted to $32 \pm 1$ parts per thousand (ppt). The stabilized mixture was then transferred to the insulated drum in the cold pit. The temperature of the insulated drum was maintained at $0^{\circ} \mathrm{C}$ by heaters attached to the drum. These heaters were controlled by a separate controller (Dowty model 72A) with thermistor temperature feedback. A back-up supply of seawater, which was maintained and continuously stirred in a separate coldroom, was used to maintain the level in the cold pit drum.

Prior to coldroom testing of the louver models, a series of tests were conducted at CRREL to evaluate and verify the equipment and instrumentation proposed for the louver icing comparisons. The spray nozzle characteristics were predicted to be the most difficult to match to the test matrix specifications, and this proved to be so. A test apparatus was set up in the calibration lab at CRREL to examine and measure the spray characteristics of various nozzles. A tap water system driven by a small peristaltic pump was connected to a pressure gauge and flow meter, which was in turn connected to the nozzles being tested. Using the flow rates calculated to satisfy the requirements of the test matrix, the various nozzles were tested. The spray patterns were observed and droplet size distributions were obtained and analyzed using the oiled-slide method. Using this data and visual observations made during previous tests, AME chose the two nozzle sizes employed in the comparison tests. The mean droplet size for the chosen nozzles was $400 \mu \mathrm{m}$.

While testing the nozzles, we evaluated various pumps and the water meter. The peristaltic pump used for the majority of the nozzle evaluation tests proved to be inadequate for long-term continuous operation. The major problems were migration and splitting of the tubing at the pump, as well as flow control at lower flow rates. A low-volume metering pump was tried next but proved inadequate due to pulsations at the lower flow rates. A magnetically driven positive-displacement gear pump was finally evaluated and found to be ideal for our application. The water meter was then tested against a stopwatch and graduated beaker and found to conform to the manufacturer's specifications at flow rates above $50 \mathrm{~mL} / \mathrm{min}$.

The test equipment was assembled and set up on an outdoor loading dock near the cold pit. The fans were installed and run in various configurations to verify compatibility with the test matrix parameters $(3-9 \mathrm{~m} / \mathrm{s})$. The pressure drop across the louvers was found to be a poor indicator of louver blockage due to the high bypass of the axial vane fans. The unobstructed pressure drop at the maximum through-vane flux was $174 \mathrm{~Pa}$, while it was $250 \mathrm{~Pa}$ when fully blocked. A final check was 


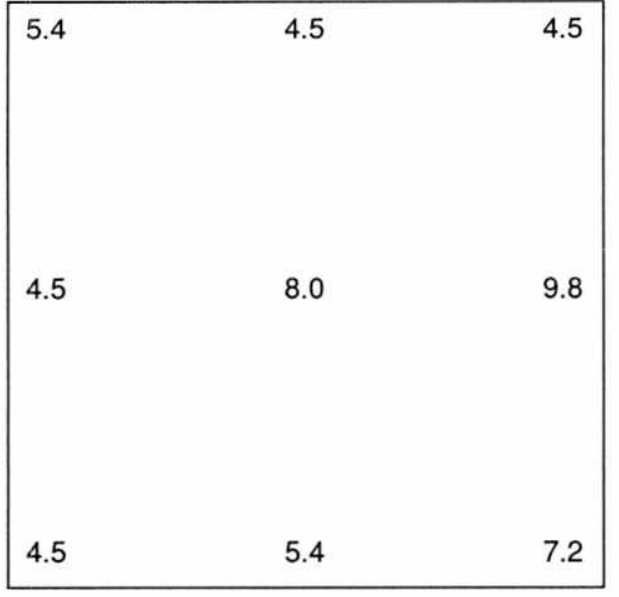

Figure 5. Air velocities $(\mathrm{m} / \mathrm{s})$ in front of the 100-series louver.

done on the spray droplet sizes, with results similar to those found in the lab: around $400 \mu \mathrm{m}$ mean diameter. AME gave the approval to run with the system as configured, and the equipment was set up in the cold pit.

A final set of equipment checks was made with the equipment in the cold pit. The seawater distribution system was hooked up and activated, and the air velocities were checked once again. The average velocity over the face of the unobstructed grid was $6 \mathrm{~m} / \mathrm{s}$ (Fig. 5). The pressure drop was
$174 \mathrm{~Pa}$ across the louvers. The data acquisition system was installed and initiated. The test system was ready for full operation.

\section{TEST PROCEDURE}

Testing proceeded following the test matrix designed by AME. The main features of the matrix included 16 separate tests conducted to evaluate the effect of air temperature, wind speed and liquid water content of the air on the rate and character of louver ice accretion (Table 1). Testing followed the procedure outlined in Table 2 . Any changes in test parameters were made during the changeover period between tests.

The actual order of tests did not follow the test matrix sequentially due to the difficulty in alternating the louvers. After the first day, test runs were grouped to minimize changeover and its associated problems and time. Labeling of the tests followed the matrix nomenclature, with the current model intake louver and its associated tests designated as 100 series and the prototype louver model and its associated tests designated as 200 series.

Prior to each new test, measurements were taken to establish system baseline levels. These included measurements of the air velocity in front of the intake louver, the pressure drop across the louver, and the water and air temperatures. Droplet samples

Table 1. Test matrix developed by AME.

\begin{tabular}{cccccc}
$\begin{array}{c}\text { Test } \\
\text { number }\end{array}$ & $\begin{array}{c}\text { Liquid water } \\
\text { content } \\
\left(\mathrm{g} / \mathrm{m}^{3}\right)\end{array}$ & $\begin{array}{c}\text { Air } \\
\text { temperature } \\
\left({ }^{\circ} \mathrm{C}\right)\end{array}$ & $\begin{array}{c}\text { Air flow } \\
\text { velocity } \\
(\mathrm{m} / \mathrm{s})\end{array}$ & $\begin{array}{c}\text { Predicted } \\
\text { freezing fraction } \\
(\%)\end{array}$ & $\begin{array}{c}\text { Predicted } \\
\text { icing rate } \\
(\mathrm{mm} / \mathrm{hr})\end{array}$ \\
\hline $\begin{array}{c}\text { 100 Series } \\
\text { Tests }\end{array}$ & $\begin{array}{c}\text { (Current model) } \\
101\end{array}$ & & & & \\
102 & 0.5 & -8.0 & 9.14 & 30.6 & 57 \\
103 & 0.5 & -12.0 & 9.14 & 48.1 & 89 \\
104 & 0.5 & -4.0 & 9.14 & 11.6 & 22 \\
105 & $0.8^{*}$ & $-10.0^{+}$ & 9.14 & 16.4 & 61 \\
106 & 0.1 & -8.0 & 9.14 & 100.0 & 37 \\
107 & 0.5 & -8.0 & 6.10 & 33.3 & 41 \\
$108^{* *}$ & 0.5 & -8.0 & 3.05 & 38.4 & 24 \\
200 Series & 1.0 & -12.0 & 9.14 & & \\
201 & & & & & \\
202 & 0.5 & -8.0 & 9.14 & 30.6 & 57 \\
203 & 0.5 & -12.0 & 9.14 & 48.1 & 22 \\
204 & 0.5 & -4.0 & 9.14 & 11.6 & 61 \\
205 & $0.8^{*}$ & $-10.0^{+}$ & 9.14 & 16.4 & 37 \\
206 & 0.1 & -8.0 & 9.14 & 100.0 & 41 \\
207 & 0.5 & -8.0 & 6.10 & 33.3 & \\
$208^{* *}$ & 0.5 & -8.0 & 3.05 & 38.4 & \\
\hline
\end{tabular}

* Changed to $1.0 \mathrm{~g} / \mathrm{m}^{3}$.

+ Changed to $-12^{\circ} \mathrm{C}$.

**Test parameters determined by CRREL to simulate "worst-case" conditions. 
Table 2. Standard test procedure.

\begin{tabular}{l} 
A. Hourly checks \\
1) Record pressure drop \\
2) Decrease spray flow to $100 \mathrm{~mL} / \mathrm{min}$ \\
3) Check air speed down center of louver $(0.3,0.6$ and \\
4) Shut down fans \\
5) Obtain salinity sample (at least $1 / 2$ vial-label vial) \\
6) Measure ice thickness on louver vanes (each louver at \\
7) Turn on fans \\
8) Turn up water \\
9) Take photographs if appropriate \\
B. Changeovers \\
1) Same as A (1) through (6) \\
2) Disconnect nozzle and bring into assembly area \\
3) Change filters in spray system \\
4) Recirculate water into tank \\
5) Collect and label ice sample from louver (put in \\
6) Clastic bag) \\
7) Change louvers if appropriate \\
8) Reconnect nozzles \\
9) Set parameters (flow, fan speed, temperature, etc.) \\
10) Check air velocities and pressure differential \\
11) Bring system into equilibrium \\
12) Start test \\
13) Obtain droplet size measurement sample (oiled slide) \\
C. Shutdown \\
1) Same as B (1) through (7) except (4) \\
2) Shut down spray system and anemometer \\
3) Bring spray hoses into assembly area \\
4) Clean up area \\
5) Secure test area \\
\hline
\end{tabular}

were also collected by momentarily exposing oilcovered culture microscope slides to droplets entrained in the air stream at a point about $100 \mathrm{~mm}$ in front of the louvers. The slides were $25.4 \times 76.2 \mathrm{~mm}$ with an 18-mm-diam. spherical well $0.5 \mathrm{~mm}$ deep at the center. Slides were coated with a 1-mm-thick film of Dow Corning Silicone 200 Fluid with a viscosity of $10,000 \mathrm{cs}$. Once the slides were exposed to droplets, they were covered with another identical oil-coated slide. Droplet samples were also collected once per hour during each test and analyzed while testing in the cold pit progressed.

Water droplet sizes were measured using a Leitz Ortholux microscope, a Sony charge-coupled camera and a Zeiss Videoplan II system. The camera was mated directly to the photo tube of the Ortholux, and the camera output was fed into the video card of the Videoplan II. Exposed slides were placed on the microscope stage, the image was focused on the Videoplan II display, and the droplet diameters were digitized. Each droplet was measured from left to right in the field, and the field was scanned from top to bottom. Diameters were recorded as the horizontal distance parallel to the bottom of the field. The slide was then indexed to a new location using the slide holder scale of the microscope stage. This process was repeated until all droplets on the slide were measured (App. A).

The pressure drop across the louvers was measured by reading the water level difference on the $\mathrm{U}$-tube manometer. The temperatures monitored were the ambient air, the water near the nozzles and in the tank, the floor, the anemometer, the back and face of the louver, and the intake and exhaust blower air. Stable room and nozzle water temperatures were necessary before testing could begin. The room temperature was thermostatically controlled, while the nozzle water temperature was varied by exposing various lengths of the feed line to the cold pit or the heated staging area where the instrumentation and pump were located. The goal was to cool the water to as close to freezing as possible without icing up the nozzles or feed lines. This was a rather crude but effective method of regulating the nozzle water temperature.

Testing was conducted in one-hour blocks of time. During this interval the DAS recorded the relative humidity, the seawater flow rate and the temperatures at 30-s intervals. At 5-minute intervals these data were averaged, and the data were saved along with the time. At the end of an hour the flow rate was decreased to a nominal rate $(\sim 100$ $\mathrm{mL} / \mathrm{min}$ ), and manual measurements of the system were made. First, a pressure differential reading was taken and recorded. Airspeed measurements were made across the midhorizon of the louver in three places: at each edge and at the center. The fans were then stopped and a salinity sample collected for later analysis. A 20-mL scintillation vial was placed beneath the dripping louver to collect a sample of the runoff liquid to analyze for salinity level. When filled, the bottles were tightly capped, labeled and stored in the water quality lab (at $23^{\circ} \mathrm{C}$ ) for later analysis. The sample labeling scheme included the spray date, the experiment and the sample number. For example, "Sample 503B4" was collected on 3 May (5/03) during the second experiment of the day (B) following the fourth hour of spraying. The tests were from two to four hours long, depending on the icing rate, and therefore two to four brine runoff samples were collected from each test. The samples were analyzed off-site (App. B).

A vernier caliper was then used to measure the total thickness of each louver fin and its associated ice accumulation at three heights across the face of 


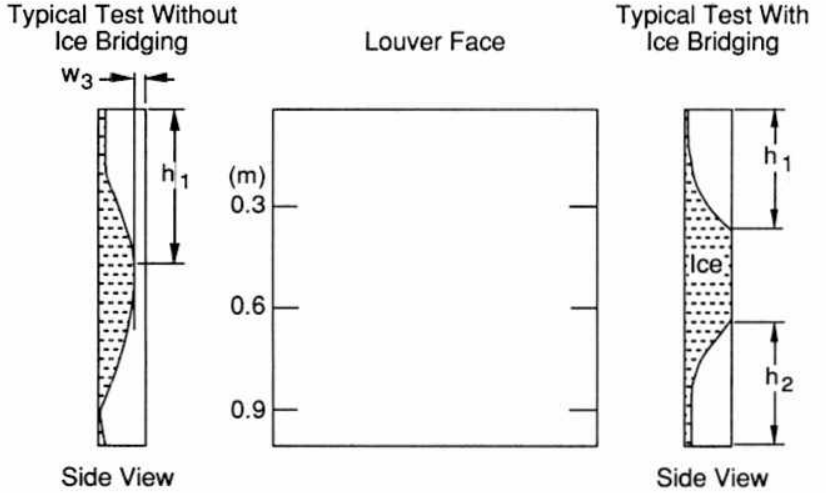

Figure 6. Ice thickness measurement nomenclature.

the louver panel: $0.3,0.6$ and $0.9 \mathrm{~m}$ down from the top of the panel (Fig. 6). The thickness of the louver fin was subtracted to yield an ice accretion value. The hourly change in the accretion value provides a rate of icing for that location. The average louver icing rate is simply the average of all the hourly accretion changes.

The tests typically ran four hours unless icing was extremely light or severe enough that ice began to bridge between adjacent vanes. At the conclusion of each test, final thickness measurements were made according to Figure 6 . At the same time, a sketch of the ice buildup on the louver was made. In tests where there was no ice bridging across adjacent louver vanes, the location of maximum ice thickness $h_{1}$ on each vane was documented along with the perpendicular clearance distance to its neighboring vane $w_{3}$. On vanes where ice bridging had occurred, $h_{1}$ was the vertical distance from the top of the louver opening to the point where bridging began. A second distance from the bottom of the louver to the lower point of bridging was recorded as $h_{2}$. A complete set of sketches with corresponding icing photographs and ice thickness measurement tables are included in Appendix C.

When a test was terminated and all other measurements were taken, ice density and salinity samples were taken from the louvers. Ice samples were collected from five locations on the louvers following each of 16 spray icing tests. For each sample a handsaw was used to make two parallel cuts approximately $15-20 \mathrm{~cm}$ apart through the ice to thelouver surface. The reduced adhesion strength of the ice due to its brine content then allowed the sample to be removed cleanly by pushing against the ice along the vane. Each sample was approximately $500 \mathrm{~g}$ and was bagged, labeled and moved to a coldroom at $-15^{\circ} \mathrm{C}$ for later analysis (App. D). The sample labeling scheme incorporated the test number and the louver fin number (in ascending order from left to right) from which the sample was taken. For example, "104 L4" was from test number 104 and louver fin number 4 . We intended to take the samples from the same locations following each test, and in general this was accomplished. For the 100-series tests using the original louver design, one sample was to be collected from each of the five fins approximately midway between the 0.3 - and 0.6-m marks. For the 200-series tests using the louver prototype with 10 fins, we sampled from the same level but from every other fin. The final ice buildup sometimes required a modified collection scheme. For example, tests 105 and 205 produced very slight icing, and there was not enough ice to sample at the outer edges. These two tests have sample numbers that reflect a two-level collection scheme near the center of the louver. The " $\mathrm{T}$ " and " $B$ " designations for these samples refer to "top" or "bottom" and document whether they were taken from just above or just below the 0.6-m mark.

\section{RESULTS AND ANALYSES}

Results and analyses are broken down into four categories: droplet size distribution, salinity, accreted ice density and accreted ice thickness. Not included is pressure drop, one of the original variables to be analyzed. The fan used to simulate the intake blower permitted a high bypass of air when blocked. Therefore, the pressure drop readings obtained during testing did not accurately indicate the blockage at the louver face and will not be considered in evaluating the performance of the two louver models.

\section{Droplet size distribution}

All of the distributions are non-Gaussian, but they have the same shape when normalized. The means of the distributions for experiments 105, 106 and 107 are considerably larger than for all the other experiments (Fig. 7). There appear to be three groups of medians. Experiments 101, 102, 103, 105, 201, 202, 204 and 205 form a group with sizes ranging from 0.003 to $0.03 \mathrm{~mm}$. The second group of experiments $(104,108,203,206,208$ and possibly 207) have sizes ranging from 0.07 to $0.10 \mathrm{~mm}$. The third group consists of experiments 106 and 107, which are significantly different from each other and from the rest. The modes of the diameters appear to have two groupings. The first group consists of experiments 102, 103, 104, 203, 207 and 208, where droplet diameters range from 0.031 to 


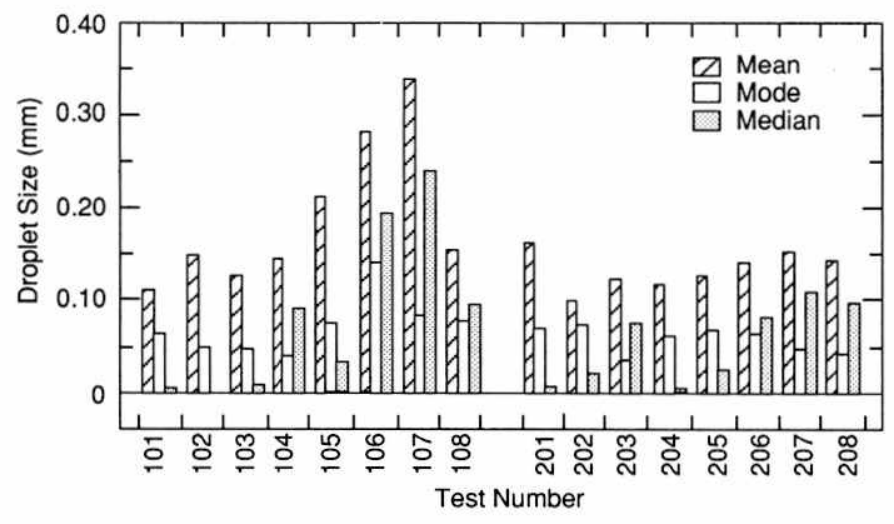

Figure 7. Droplet analysis results.

$0.044 \mathrm{~mm}$. The second group consists of experiments 101, 105, 107, 108, 201, 202, 204, 205 and 206, in which diameters range from 0.056 to $0.080 \mathrm{~mm}$. Again, experiment 106 is significantly different from either of the other two groups. The standard errors of the distributions indicate that the largest errors were in experiments 105, 106 and 107. Therefore, experiments 105, 106 and 107 appear to have had some variation in the spray configuration that set them apart from the other groupings. Possible causes of the variation could be changes in flow rates through the nozzles, changes in relative humidity during the experiment, or programmed changes in nozzle configuration.

\section{Salinity}

The full results of the salinity analysis are contained in Appendix B. A summary of those results is shown in Table 3. The mean brine measurements for the prototype louver are significantly higher than those of the original louver in most cases. The samples from the prototype louver averaged at least $11 \%$ more saline for five out of eight tests, the same for one test, and 6 and $23 \%$ less saline for the other two tests.
The runoff salinity is higher than that of the original spray because of brine drainage and expulsion from the ice building up on the louver. Greater runoff salinity from the prototype louver is an indication that there is more ice present from which the brine drainage can occur. However, the importance of these data should not be overestimated. Although there is great confidence in the accuracy and precision of our salinity measurements, the sample collection points varied from test to test. The runoff water was sometimes collected from beneath the middle of the louver, while at other times it may have been collected from beneath the right or left sides due to the drainage characteristics for an individual test. The sampling points were not recorded but could be responsible for the large range in values.

\section{Sea spray ice density}

The ice density measurements appear in Appendix D. Table 4 summarizes the density analysis. The ice densities obtained from the original design are all slightly lower than those from the prototype. The mean density ranged from 0.865 to $0.904 \mathrm{~g} / \mathrm{cm}^{3}$. However, the scatter between the five measurements made for each test was considerable, as shown by the standard deviation. Based on these data and the appearance of the ice, we cannot say that there was a significant difference in the ice density from test to test.

\section{Louver icing distribution and rate}

The previous three sections detail analyses that were performed to characterize the spray icing environment to which the panels were subjected. Comparison of the ice density and runoff brine concentration between the 100 - and 200-series tests helps to determine whether the two louvers were indeed subjected to similar icing conditions. This

Table 3. Mean and range of salinity measurements for each test.

\begin{tabular}{|c|c|c|c|c|c|c|c|}
\hline \multirow{3}{*}{$\begin{array}{c}\text { Test } \\
\text { number }\end{array}$} & \multirow{3}{*}{$\begin{array}{l}\text { Liquid water } \\
\text { content } \\
\left(\mathrm{g} / \mathrm{m}^{3}\right)\end{array}$} & \multirow{3}{*}{$\begin{array}{c}\text { Air } \\
\text { temperature } \\
\left({ }^{\circ} \mathrm{C}\right)\end{array}$} & \multirow{3}{*}{$\begin{array}{c}\text { Air velocity } \\
(\mathrm{m} / \mathrm{s})\end{array}$} & \multicolumn{4}{|c|}{ Runoff salinity (ppt) } \\
\hline & & & & \multicolumn{2}{|c|}{ Original } & \multicolumn{2}{|c|}{ Prototype } \\
\hline & & & & $\overline{\text { Mean }}$ & Range & Mean & Range \\
\hline 1 & 0.5 & -8 & 9.14 & 94 & 20 & 111 & 22 \\
\hline 2 & 0.5 & -12 & 9.14 & 136 & 46 & 165 & 12 \\
\hline 3 & 0.5 & -4 & 9.14 & 53 & 24 & 62 & 6 \\
\hline 4 & 1.0 & -8 & 9.14 & 82 & 6 & 117 & 9 \\
\hline 5 & 0.1 & -8 & 9.14 & 119 & 9 & 108 & 28 \\
\hline 6 & 0.5 & -8 & 6.10 & 92 & 21 & 93 & 50 \\
\hline 7 & 0.5 & -8 & 3.05 & 93 & 23 & 110 & 16 \\
\hline 8 & 1.0 & -12 & 9.14 & 141 & 30 & 115 & 84 \\
\hline
\end{tabular}


Table 4. Summary of ice density data.

\begin{tabular}{|c|c|c|c|c|c|c|c|}
\hline \multirow{3}{*}{$\begin{array}{c}\text { Test } \\
\text { number }\end{array}$} & \multirow{3}{*}{$\begin{array}{l}\text { Liquid water } \\
\text { content } \\
\left(\mathrm{g} / \mathrm{m}^{3}\right)\end{array}$} & \multirow{3}{*}{$\begin{array}{c}\text { Air } \\
\text { temperature } \\
\left({ }^{\circ} \mathrm{C}\right)\end{array}$} & \multirow{3}{*}{$\begin{array}{l}\text { Air velocity } \\
(\mathrm{m} / \mathrm{s})\end{array}$} & \multicolumn{4}{|c|}{ Ice density $\left(\mathrm{g} / \mathrm{cm}^{3}\right)$} \\
\hline & & & & \multicolumn{2}{|c|}{ Original } & \multicolumn{2}{|c|}{ Prototype } \\
\hline & & & & Mean & St. Dev. & Mean & St. Dev. \\
\hline 1 & 0.5 & -8 & 9.14 & 0.888 & 0.014 & 0.892 & 0.016 \\
\hline 2 & 0.5 & -12 & 9.14 & 0.899 & 0.012 & 0.903 & 0.015 \\
\hline 3 & 0.5 & -4 & 9.14 & 0.871 & 0.010 & 0.878 & 0.018 \\
\hline 4 & 1.0 & -8 & 9.14 & 0.865 & 0.003 & 0.868 & 0.008 \\
\hline 5 & 0.1 & -8 & 9.14 & 0.895 & 0.008 & 0.901 & 0.010 \\
\hline 6 & 0.5 & -8 & 6.10 & 0.866 & 0.011 & 0.890 & 0.018 \\
\hline 7 & 0.5 & -8 & 3.05 & 0.876 & 0.013 & 0.904 & 0.014 \\
\hline 8 & 1.0 & -12 & 9.14 & 0.897 & 0.017 & 0.899 & 0.010 \\
\hline
\end{tabular}

*Ice densities in $\left(\mathrm{g} / \mathrm{cm}^{3}\right)$

${ }^{+}$Liquid water content

section discusses observations that provide a more direct indication of louver performance: ice accretion rates of the two louver models under similar conditions.

Ice typically accreted sooner and at a faster rate onto the louver vanes in the area of maximum spray water delivery. Maximum delivery was affected by a combination of the initial spray concentration and runoff on the louver vanes. The ice accretion rate varied from test to test, depending on air temperature, water delivery rate or liquid water content (LWC), and air flow velocity (App. C). In tests with higher LWC, higher air temperatures or both, brine runoff was more pronounced, which contributed to greater ice buildup on the lower half of the panel.

Figure 8 shows the average ice accretion rates for the eight pairs of tests. The icing rate for each 100 -series test was very similar to that of its 200series counterpart. Disregarding the $4.06-\mathrm{mm} / \mathrm{hr}$ difference in test 8 , the average difference between the 100 - and 200 -series tests was only $0.65 \mathrm{~mm} / \mathrm{hr}$. Given that the accretion rates were essentially the same, since the prototype design has twice as many louver fins, its intake area that would be blocked by ice is roughly doubled.

The tables in Appendix $\mathrm{C}$ show that ice bridging between adjacent vanes occurred only once during testing of the original design (on vane 6 during test number 104), whereas the prototype suffered bridging to some degree in five out of eight tests. This is due to the decreased distance between louver vanes on the prototype. The prototype has only a $70-\mathrm{mm}$ gap between vanes, whereas the original design has a 145-mm gap. Under similar conditions, therefore, bridging is more likely to occur with the newer louver design. Based on this information, we conclude that the intake area of the prototype louver will ice faster and will be more likely to be

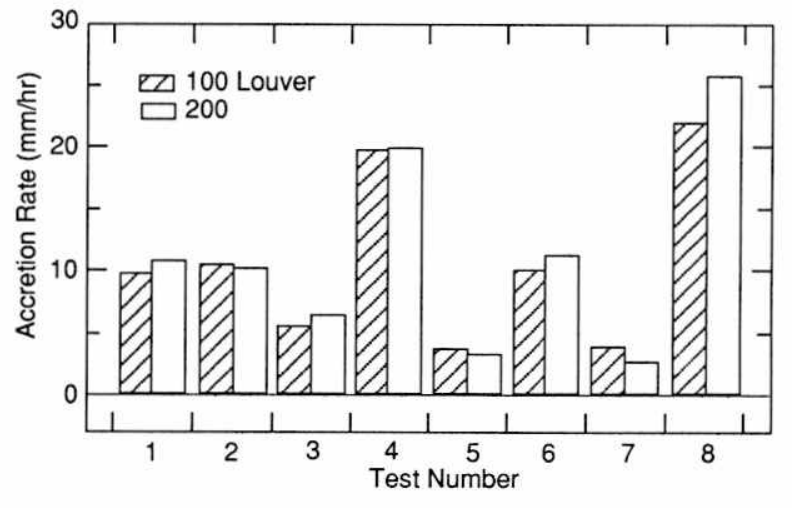

Figure 8. Average ice accretion rates.

blocked by spray ice accretion than the original design.

\section{CONCLUSION}

Two sets of louver models were tested at CRREL in a large low-temperature seawater facility. The louvers, a standard straight vane and a prototype angled vane, were configured in such a manner as to closely model conditions that may be encountered by the ship on which they are to be used. A series of 16 tests were run under various conditions in which reconstituted seawater, entrained in a moving air stream, was sucked into the louver. Ice densities, runoff salinity, accreted ice thickness and various test variables were recorded at one-hour intervals to evaluate each vane's susceptibility to icing. Tests indicate that ice accretion rates do not vary appreciably between designs, although the closer spacing between the louvers of the prototype design will result in faster ice bridging between adjacent vanes and thus reduce the airflow capacity through the louver. 


\section{APPENDIX A: SPRAY DROPLET SIZE DISTRIBUTION DATA}

Droplet diameter data were processed using two software routines provided with the Zeiss Videoplan II system. The first routine puts the data into histogram format and compares the data to a normal distribution. Data were placed into a 20-cell histogram over a 0 - to $3.0-\mathrm{mm}$ range and compared to a general Gaussian distribution. Droplet diameter data were examined using three formats: tabu- lar, histogram-normal distribution and cumulative. Table A1 contains general statistical data derived from these analyses. Mean droplet sizes were on average less than one order of magnitude smaller than desired $(1 \mathrm{~mm})$. Droplet size was compromised to satisfy other more important constraints, most notably flow rate (air stream liquid water content).

Table A1. Droplet size statistics.

\begin{tabular}{|c|c|c|c|}
\hline \multirow[b]{2}{*}{ Test } & \multicolumn{3}{|c|}{ Droplet sizes $(\mathrm{mm})$} \\
\hline & Mean & Mode & Median \\
\hline \multicolumn{4}{|c|}{100 Series Tests } \\
\hline 101 & 0.103 & 0.057 & 0.003 \\
\hline 102 & 0.145 & 0.044 & 0.000 \\
\hline 103 & 0.122 & 0.042 & 0.004 \\
\hline 104 & 0.141 & 0.034 & 0.085 \\
\hline 105 & 0.209 & 0.071 & 0.031 \\
\hline 106 & 0.277 & 0.138 & 0.191 \\
\hline 107 & 0.336 & 0.080 & 0.239 \\
\hline 108 & 0.152 & 0.072 & 0.089 \\
\hline \multicolumn{4}{|c|}{200 Series Tests } \\
\hline 201 & 0.160 & 0.064 & 0.005 \\
\hline 202 & 0.098 & 0.069 & 0.014 \\
\hline 203 & 0.121 & 0.031 & 0.071 \\
\hline 204 & 0.112 & 0.058 & 0.004 \\
\hline 205 & 0.122 & 0.065 & 0.021 \\
\hline 206 & 0.138 & 0.063 & 0.080 \\
\hline 207 & 0.149 & 0.044 & 0.106 \\
\hline 208 & 0.142 & 0.041 & 0.095 \\
\hline
\end{tabular}




\section{APPENDIX B: SALINITY MEASUREMENT PROCEDURE}

This appendix describes the methodology employed in deriving the salinity of brine samples gathered during and after testing. Sample preparation, dilution and rinsing methods are described, as well as techniques used to verify the accuracy of the measurements. Salinity measurements were done off-site in the CRREL water quality lab. Table B3 contains data used in the derivation of salinities for each sample.

\section{Sample preparation}

The instrument used to measure the brine sample salinities was a Beckman Industrial SoluBridge (Model RB53494) with a measurement range of 040 parts per thousand (ppt). The meter's precision is approximately $0.05 \mathrm{ppt}$ at the lower end of the range and increases linearly to $0.25 \mathrm{ppt}$ at the upper extreme. The spray water salinity was nominally 32 ppt (standard seawater salt concentration). However, the runoff water was more saline due to brine expulsion and drainage during ice formation. Since the salinity level of the runoff was much higher than the meter's maximum limit, the samples were diluted for analysis. The following equation was used to calculate the salinity of the original brine solution $S_{\mathrm{c}}$ from the dilution procedure:

$$
S_{\mathrm{c}}=S_{\mathrm{m}}\left[w_{2} /\left(w_{2}-w_{1}\right)\right]
$$

where $S_{\mathrm{m}}=$ measured salinity of diluted sample (ppt)

$w_{1}=$ weight of diluent $(\mathrm{g})$

$w_{2}=$ weight of brine plus distilled water dilution $(\mathrm{g})$.

Note that eq B1 produces a weight-weight salinity concentration and assumes that

$$
\begin{aligned}
& \text { ppt }(w t / w t)=(\text { grams of } \\
& \text { sea salt/grams of solution }) \cdot 1000 \text {. }
\end{aligned}
$$

For example

(2.50 g sea salt/ 500 g solu-

tion) $\cdot 1000=5.0 \mathrm{ppt}(\mathrm{wt} / \mathrm{wt})$.

Often the following weight-volume convention is used for measuring salinity:

$$
\begin{aligned}
& \text { ppt }(\text { wt } / \mathrm{vol})=(\text { grams of } \\
& \text { sea salt } / \mathrm{mL} \text { of solution }) \cdot 1000
\end{aligned}
$$

The former convention was chosen for this analysis due to the accuracy, ease and speed of sample weighing vs laborious manipulation of small volumes. Proof will later be provided to show that in the range of concentrations encountered during these tests, the results obtained with the two methods are identical.

\section{Salinity measurements}

For the first two days of testing (May 5 and 6), a Sartorius electronic balance (Model B4100) was used to weigh the solutions. It has a digital readout to the nearest $0.1 \mathrm{~g}$. The wide range in calculated salinities encountered within some test groups indicated that there might be an error in the technique. Every repeat measurement, however, produced results within 5 ppt of the previous measurements. Desiring better precision than $5 \mathrm{ppt}$, we examined the precision of the balance as the possible error source. Therefore, we continued the analysis on 7 May using a Setra electronic balance (Model 5000L), which has a digital display to the nearest $0.01 \mathrm{~g}$. In addition, standard seawater solutions in the range of interest were made up on May 7 and measured both before and after analyses of the unknowns that were run on that date. The more questionable samples from the first two days were re-analyzed, and there was no appreciable difference from the earlier measurements, confirming that the precision of the original equipment was adequate and that the wide range in salinities within specific test groups was real.

The wet chemistry of this procedure utilized double-deionized water (DDW) with a minimum resistivity of $10 \mathrm{M} \Omega-\mathrm{cm}$. A clean, dry $40-\mathrm{mL}$ beaker was placed on the balance pan and tared. Between 25 and $35 \mathrm{~g}$ of DDW was added from a $100-\mathrm{mL}$ burette set up over the beaker. The weight was recorded as $w_{1}$ for eq $\mathrm{B} 1$. Approximately $4 \mathrm{~mL}$ of the brine sample were added to the beaker using a 4-mL pipette, and the new weight was recorded as $w_{2}$. The diluted solution was stirred with the probe of an Omega digital thermometer (model 866). The Beckman's sampling reservoir was rinsed with the analyte solution four or five times before the solution was retained in the reservoir for measurement. The solution's temperature was dialed into the Beckman meter, and a null reading was obtained by adjusting the salinity-conductivity dial. This salinity reading was recorded as $S_{\mathrm{m}}$.

The salinity probe's reservoir was then emptied, and the outside of the probe was washed in a stream of DDW from a squeeze bottle before rinsing the inside of the reservoir four or five times with DDW from a $100-\mathrm{mL}$ beaker. It was rinsed two or 
three more times with DDW from a second 100-mL beaker and filled one last time to zero-check the Beckman meter. The conductivity of the final rinse water in the second 100-mL beaker was constantly monitored using a HACHConductivity/TDSmeter (Model 44600) to ensure its purity. This final rinse water was always replaced when its conductivity reached $10 \mu \mathrm{mhos}-\mathrm{cm}$. A zero reading on the Beckman with rinse water in the reservoir thus ensured that the previous sample had been completely flushed out of the probe. The outside tip of the 4-mL pipette was rinsed off with the squeeze bottle. Rinse water was also forced down through the inside of the pipette three or four times to remove all brine from the previous sample. The 40$\mathrm{mL}$ dilution beaker was rinsed four or five times using the squeeze bottle and wiped dry with a clean "ChemWipe" before replacing it on the balance pan for the next dilution. This elaborate rinsing procedure eliminated the possibility of nonaccountable sample dilution and cross-contamination of samples. At random intervals the cleanliness of the dilution beaker was checked by filling it with DDW and measuring zero salinity with the Beckman meter.

The seawater standards were made up in the following manner. The same sea salt that was used to make up the spray water for the icing tests was weighed into tared $500-\mathrm{mL}$ volumetric flasks. The amounts of sea salt that were weighed out to produce their respective nominal concentrations are shown in Table B1. DDW was added to each flask to bring the total weight of the salt and water up to $500 \mathrm{~g}$. The flasks were then shaken at intervals over a one-hour period to ensure complete mixing.

As previously stated, the standards were analyzed with the Beckman both before and after the unknowns were analyzed on May 7. The results of these analyses are also shown in Table B1. The agreement between the before and after measurements and between the nominal and the measured concentrations are evidence that the technique and the improved instrumentation were acceptable for accurately measuring sample salinity to within 1 ppt. The six runoff samples that were originally tested using the less precise balance and then retested using the Setra agreed to within $3 \mathrm{ppt}$ (samples 101-C2, 102-B2, 103-A3, 201-C1, 204-D3 and 205-A3). Therefore, the conclusion was drawn that the accuracy of the measurements performed on May 5 and 6 is $\pm 3 \mathrm{ppt}$, whereas those performed on May 7 are accurate to $\pm 1 \mathrm{ppt}$, and the difference is wholly attributable to the use of the more precise electronic balance. Table B2 contains data obtained during salinity measurements.
Table B1. Weight/weight seawater standards.*

\begin{tabular}{rccc}
\multirow{2}{*}{$\begin{array}{c}\text { Salt } \\
(\mathrm{g})\end{array}$} & $\begin{array}{c}\text { Nominal concentration } \\
(\text { ppt wt/wt) }\end{array}$ & \multicolumn{2}{c}{ Measured concentrations $(\mathrm{ppt})$} \\
\cline { 3 - 4 } & & Before & After \\
\hline 2.50 & 5.0 & 5.1 & 5.1 \\
3.75 & 7.5 & 7.8 & 7.8 \\
5.00 & 10.0 & 10.5 & 10.5 \\
7.50 & 15.0 & 15.6 & 15.8 \\
10.00 & 20.0 & 20.1 & 20.4 \\
12.50 & 25.0 & 26.1 & 26.1 \\
\hline
\end{tabular}

*With the salt amounts listed dissolved in water such that the total weight of water and salt equal $500 \mathrm{~g}$. (Concentrations were measured both before and after the sample unknowns were analyzed.)

\section{Comparison of concentration conventions}

A simple experiment conducted on May 10 showed that either the weight-weight or the weight-volume convention is adequate for analyzing concentrations in the 1-32 ppt range with a desired precision of \pm 1 ppt. Six seawater standards were made up according to the weight-volume convention and tested with the Beckman meter. They produced deviations from the nominal concentrations comparable to those observed with the weight-weight standards. These weight-volume standards were made up in the following manner. The most concentrated standard was made up by weighing $6.25 \mathrm{~g}$ of sea salt into a clean and tared 200 -mL volumetric flask, which was then filled to the mark and shaken to complete mixing. The nominal concentration of this standard was calculated to be 31.25 ppt using eq B3. Successively smaller portions of this solution were then used to make up five weaker standards.

Using 5-and 10-mL pipettes, the volumes shown as $v_{1}$ in Table B3 were measured into $50-\mathrm{mL}$ volumetric flasks and diluted to the marks with DDW. The formula used to calculate the concentration of a dilution $C_{2}$ is

$$
C_{2}=C_{1} \cdot v_{1} / v_{2}
$$

where $C_{1}=$ concentration of the original solution (ppt)

$v_{1}=$ volume of the original solution $(\mathrm{mL})$

$v_{2}=$ volume of the diluted solution $(\mathrm{mL})$.

For example

$$
\begin{aligned}
& (31.25 \mathrm{ppt} \cdot 40 \mathrm{~mL}) / \\
& 50 \mathrm{~mL}=25.00 \mathrm{ppt}(\mathrm{wt} / \mathrm{vol}) .
\end{aligned}
$$


Table B2. Louver ice runoff salinity data (see eq B1).

\begin{tabular}{|c|c|c|c|c|c|c|c|}
\hline \multirow{2}{*}{$\begin{array}{l}\text { Sample } \\
\text { number }\end{array}$} & \multirow{2}{*}{$\begin{array}{l}\text { Test } \\
\text { date }\end{array}$} & \multicolumn{2}{|c|}{ Analysis } & \multirow{2}{*}{$\begin{array}{l}w_{1} \\
(g)\end{array}$} & \multirow{2}{*}{$\begin{array}{l}w_{2} \\
(g)\end{array}$} & \multicolumn{2}{|c|}{ Salinity (ppt) } \\
\hline & & Date & Time & & & Measured & Calculated \\
\hline $101-\mathrm{C} 1$ & 503 & 505 & 1830 & 34.5 & 38.8 & 11.1 & 100 \\
\hline $101-C 2$ & 503 & 505 & 1722 & 30.7 & 34.9 & 10.1 & 84 \\
\hline $101-C 2$ & 503 & 507 & 2015 & 28.1 & 32.5 & 11.4 & 83 \\
\hline $101-\mathrm{C} 3$ & 503 & 505 & 1750 & 32.3 & 36.7 & 12.4 & 103 \\
\hline $101-\mathrm{C} 3$ & 503 & 505 & 1922 & 28.7 & 32.9 & 12.5 & 98 \\
\hline $101-C 4$ & 503 & 505 & 1450 & 30.1 & 34.3 & 11.9 & 97 \\
\hline Mean & & & & & & & 94 \\
\hline \multicolumn{4}{|c|}{ Standard Deviation } & & & & 8 \\
\hline 102-B1 & 503 & 505 & 1430 & 31.4 & 35.2 & 17.5 & 162 \\
\hline 102-B2 & 503 & 505 & 1850 & 31.7 & 36.1 & 16.9 & 139 \\
\hline 102-B2 & 503 & 507 & 2022 & 34.8 & 39.0 & 14.7 & 138 \\
\hline 102-B3 & 503 & 505 & 1815 & 31.3 & 36.0 & 15.1 & 116 \\
\hline 102-B4 & 503 & 505 & 1700 & 30.8 & 35.3 & 16.1 & 126 \\
\hline Mean & & & & & & & 136 \\
\hline \multicolumn{4}{|c|}{ Standard Deviation } & & & & 15 \\
\hline 103-A1 & 504 & 505 & 1735 & 30.6 & 34.9 & 7.7 & 62 \\
\hline $103-\mathrm{A} 2$ & 504 & 505 & 1910 & 31.3 & 35.5 & 7.7 & 65 \\
\hline $103-\mathrm{A} 3$ & 504 & 505 & 1800 & 32.7 & 36.7 & 4.5 & 41 \\
\hline $103-\mathrm{A} 3$ & 504 & 507 & 2028 & 24.4 & 28.7 & 6.5 & 43 \\
\hline Mean & & & & & & & 53 \\
\hline \multicolumn{4}{|c|}{ Standard Deviation } & & & & 11 \\
\hline 104-C1 & 505 & 506 & 843 & 30.5 & 34.6 & 9.8 & 82 \\
\hline $104-\mathrm{C} 2$ & 505 & 506 & 910 & 26.1 & 30.2 & 10.8 & 79 \\
\hline $104-\mathrm{C} 3$ & 505 & 506 & 919 & 26.1 & 30.6 & 12.5 & 85 \\
\hline Mean & & & & & & & 82 \\
\hline \multicolumn{4}{|c|}{ Standard Deviation } & & & & 2 \\
\hline 105-B1 & 505 & 506 & 848 & 29.9 & 34.2 & 15.5 & 123 \\
\hline 105-B2 & 505 & 506 & 930 & 30.9 & 35.1 & 14.4 & 120 \\
\hline 105-B3 & 505 & 506 & 830 & 32.2 & 36.5 & 13.5 & 115 \\
\hline 105-B4 & 505 & 506 & 924 & 30.5 & 34.7 & 14.4 & 119 \\
\hline Mean & & & & & & & 119 \\
\hline \multicolumn{4}{|c|}{ Standard Deviation } & & & & 3 \\
\hline 106-B1 & 506 & 507 & 2210 & 29.8 & 34.2 & 10.3 & 81 \\
\hline 106-B2 & 506 & 507 & 2118 & 28.0 & 32.3 & 12.0 & 90 \\
\hline 106-B3 & 506 & 507 & 2145 & 26.5 & 31.2 & 15.4 & 102 \\
\hline $106-B 4$ & 506 & 507 & 2140 & 26.4 & 30.8 & 13.7 & 96 \\
\hline Mean & & & & & & & 92 \\
\hline \multicolumn{4}{|c|}{ Standard Deviation } & & & & 8 \\
\hline $107-\mathrm{C} 1$ & 506 & 507 & 2130 & 30.8 & 35.2 & 11.5 & 93 \\
\hline $107-\mathrm{C} 2$ & 506 & 507 & 2156 & 29.6 & 33.9 & 14.0 & 108 \\
\hline $107-\mathrm{C} 3$ & 506 & 507 & 2215 & 28.4 & 32.7 & 11.3 & 85 \\
\hline $107-\mathrm{C} 4$ & 506 & 507 & 2125 & 28.5 & 32.7 & 11.0 & 85 \\
\hline Mean & & & & & & & 93 \\
\hline \multicolumn{4}{|c|}{ Standard Deviation } & & & & 9 \\
\hline 108-A1 & 506 & 507 & 2135 & 29.6 & 34.0 & 20.0 & 155 \\
\hline $108-\mathrm{A} 2$ & 506 & 507 & 2201 & 30.9 & 35.4 & 16.0 & 126 \\
\hline Mean & & & & & & & 141 \\
\hline
\end{tabular}


Table B2 (cont'd).

\begin{tabular}{|c|c|c|c|c|c|c|c|}
\hline \multirow{2}{*}{$\begin{array}{l}\text { Sample } \\
\text { number }\end{array}$} & \multirow{2}{*}{$\begin{array}{l}\text { Test } \\
\text { date }\end{array}$} & \multicolumn{2}{|c|}{ Analysis } & \multirow{2}{*}{$\begin{array}{l}w_{1} \\
(g)\end{array}$} & \multirow{2}{*}{$\begin{array}{l}w_{2} \\
(g)\end{array}$} & \multicolumn{2}{|c|}{ Salinity (ppt) } \\
\hline & & Date & Time & & & Measured & Calculated \\
\hline 201-C1 & 504 & 505 & 1500 & 36.1 & 40.6 & 10.8 & 97 \\
\hline 201-C1 & 504 & 507 & 2035 & 30.8 & 35.1 & 12.0 & 97 \\
\hline 201-C2 & 504 & 505 & 1835 & 32.2 & 36.4 & 13.4 & 116 \\
\hline 201-C3 & 504 & 505 & 1705 & 30.3 & 34.7 & 15.0 & 118 \\
\hline 201-C3 & 504 & 505 & 1715 & 30.9 & 35.2 & 14.2 & 116 \\
\hline 201-C3 & 504 & 505 & 1915 & 28.9 & 33.0 & 14.8 & 119 \\
\hline 201-C4 & 504 & 505 & 1730 & 30.9 & 35.2 & 13.4 & 110 \\
\hline Mean & & & & & & & 111 \\
\hline \multicolumn{4}{|c|}{ Standard Deviation } & & & & 9 \\
\hline 202-A1 & 503 & 505 & 1330 & 32.3 & 36.7 & 19.1 & 159 \\
\hline 202-A2 & 503 & 505 & 1410 & 35.3 & 39.4 & 16.6 & 160 \\
\hline 202-A3 & 503 & 505 & 1400 & 32.5 & 36.8 & 20.0 & 171 \\
\hline 202-A3 & 503 & 505 & 1415 & 35.6 & 39.6 & 16.9 & 167 \\
\hline 202-A3 & 503 & 505 & 1420 & 28.9 & 31.4 & 13.3 & 167 \\
\hline Mean & & & & & & & 165 \\
\hline \multicolumn{4}{|c|}{ Standard Deviation } & & & & 5 \\
\hline 203-B1 & 504 & 505 & 1824 & 31.4 & 35.6 & 7.7 & 65 \\
\hline 203-B2 & 504 & 505 & 1435 & 31.4 & 35.3 & 6.9 & 62 \\
\hline 203-B3 & 504 & 505 & 1903 & 30.1 & 34.4 & 7.4 & 59 \\
\hline Mean & & & & & & & 62 \\
\hline \multicolumn{4}{|c|}{ Standard Deviation } & & & & 2 \\
\hline 204-D1 & 504 & 505 & 1505 & 30.4 & 34.8 & 15.0 & 119 \\
\hline 204-D2 & 504 & 505 & 1808 & 31.1 & 35.2 & 14.2 & 122 \\
\hline 204-D3 & 504 & 505 & 1443 & 30.3 & 34.6 & 14.0 & 113 \\
\hline 204-D3 & 504 & 507 & 2040 & 27.9 & 31.9 & 14.8 & 116 \\
\hline Mean & & & & & & & 117 \\
\hline \multicolumn{4}{|c|}{ Standard Deviation } & & & & 3 \\
\hline 205-A1 & 505 & 506 & 900 & 30.0 & 33.8 & 13.9 & 124 \\
\hline 205-A2 & 505 & 506 & 915 & 28.5 & 32.8 & 14.8 & 113 \\
\hline 205-A3 & 505 & 506 & 855 & 33.6 & 38.1 & 11.3 & 95 \\
\hline 205-A3 & 505 & 507 & 2045 & 29.3 & 33.7 & 12.5 & 96 \\
\hline 205-A4 & 505 & 506 & 838 & 30.4 & 34.7 & 14.1 & 114 \\
\hline Mean & & & & & & & 108 \\
\hline \multicolumn{4}{|c|}{ Standard Deviation } & & & & 11 \\
\hline 206-B1 & 507 & 507 & 2055 & 28.9 & 33.3 & 15.9 & 121 \\
\hline 206-B2 & 507 & 507 & 2106 & 26.3 & 30.9 & 14.0 & 93 \\
\hline 206-B3 & 507 & 507 & 2112 & 31.5 & 36.1 & 10.9 & 86 \\
\hline 206-B4 & 507 & 507 & 2012 & 29.3 & 33.6 & 9.0 & 71 \\
\hline Mean & & & & & & & 93 \\
\hline \multicolumn{4}{|c|}{ Standard Deviation } & & & & 18 \\
\hline 207-C1 & 507 & 507 & 2235 & 29.8 & 34.0 & 15.0 & 121 \\
\hline 207-C2 & 507 & 507 & 2240 & 31.1 & 35.3 & 12.8 & 105 \\
\hline 207-C3 & 507 & 507 & 2245 & 29.2 & 33.5 & 13.8 & 108 \\
\hline 207-C4 & 507 & 507 & 2250 & 27.8 & 32.3 & 14.9 & 106 \\
\hline Mean & & & & & & & 110 \\
\hline \multicolumn{4}{|c|}{ Standard Deviation } & & & & 6 \\
\hline 208-A1 & 507 & 507 & 2149 & 28.9 & 33.6 & 21.9 & 157 \\
\hline 208-A2 & 507 & 507 & 2050 & 30.7 & 34.9 & 8.8 & 72 \\
\hline Mean & & & & & & & 115 \\
\hline
\end{tabular}

Note: Samples analyzed on 7 May (507) were weighed with an electronic balance having an additional digit of accuracy. 
After shaking, the salinity of each new standard was measured. These results are also shown in Table B3.

Evaluation of the data indicates that the measured concentrations are all within $1 \mathrm{ppt}$ of the nominal values, with the one exception being the weakest standard. The largest deviation for the weight-weight standards was $1.1 \mathrm{ppt}$ (the most concentrated solution in Table B1). The two methods of defining ppt concentration are essentially identical for this equipment and in this range of interest.
Table B3. Nominal and measured concentrations of weight-volume seawater standards.

\begin{tabular}{lccc}
$\begin{array}{l}\mathrm{v}_{1} \\
(m L)\end{array}$ & $\begin{array}{c}\mathrm{v}_{2} \\
(m L)\end{array}$ & $\begin{array}{c}\text { Nominal } \\
\text { concentration } \\
(p p t \text { wt/vol })\end{array}$ & $\begin{array}{c}\text { Measured } \\
\text { concentrations } \\
(p p t)\end{array}$ \\
\hline 50 & 50 & 31.25 & 32.0 \\
40 & 50 & 25.00 & 25.9 \\
30 & 50 & 18.75 & 19.2 \\
20 & 50 & 12.50 & 12.9 \\
15 & 50 & 9.38 & 9.2 \\
10 & 50 & 6.25 & 8.2 \\
\hline
\end{tabular}




\section{APPENDIX C: LOUVER ICE THICKNESS DATA}

This appendix contains data and information on ice accretion on the intake louver vane models. Each sketch of the final ice distribution is accompanied by its corresponding photograph and data. 100-series louver tests were conducted with the original design model, while 200-series tests were conducted with the prototype louver model.

Table C1. Ice thickness in test 101.

\begin{tabular}{|c|c|c|c|c|c|c|c|c|c|}
\hline \multirow{2}{*}{$\begin{array}{l}\text { Elapsed } \\
\text { time } \\
\text { (hours) }\end{array}$} & \multirow{2}{*}{$\begin{array}{l}\text { Dist. from } \\
\text { louver top } \\
\qquad(\mathrm{m})\end{array}$} & \multicolumn{7}{|c|}{ Ice thickness (mm) } & \multirow{2}{*}{$\begin{array}{c}\text { Average } \\
\text { accretion rate } \\
(\mathrm{mm} / \mathrm{hr})\end{array}$} \\
\hline & & Vane 1 & 2 & 3 & 4 & 5 & 6 & Average & \\
\hline \multirow[t]{3}{*}{1} & 0.3 & 2 & 13 & 19 & 13 & 9 & 4 & 9.7 & \\
\hline & 0.6 & $<1$ & 9 & 18 & 18 & 18 & 4 & 11.2 & \\
\hline & 0.9 & $<1$ & 7 & 32 & 33 & 15 & 5 & 15.2 & 11.9 \\
\hline \multirow[t]{3}{*}{2} & 0.3 & 9 & 21 & 28 & 21 & 17 & 6 & 16.8 & \\
\hline & 0.6 & 5 & 34 & 28 & 24 & 17 & 6 & 18.8 & \\
\hline & 0.9 & 6 & 19 & 52 & 45 & 14 & 4 & 22.1 & 7.1 \\
\hline \multirow[t]{3}{*}{3} & 0.3 & 17 & 35 & 46 & 26 & 19 & 8 & 24.9 & \\
\hline & 0.6 & 11 & 55 & 47 & 32 & 18 & 5 & 27.7 & \\
\hline & 0.9 & 4 & 45 & 89 & 57 & 11 & 3 & 34.5 & 9.9 \\
\hline \multirow[t]{7}{*}{4} & 0.3 & 28 & 47 & 49 & 62 & 29 & 12 & 37.6 & \\
\hline & 0.6 & 18 & 67 & 53 & 64 & 21 & 5 & 37.7 & \\
\hline & 0.9 & 9 & 61 & 91 & 61 & 11 & 3 & 39.4 & 9.1 \\
\hline & & \multicolumn{7}{|c|}{ Average ice accretion rates $(\mathrm{mm} / \mathrm{hr})$} & \\
\hline & 0.3 & 6.9 & 11.7 & 12.2 & 15.5 & 7.1 & 3.1 & & \\
\hline & 0.6 & 4.3 & 16.8 & 13.2 & 15.8 & 5.3 & 1.0 & & \\
\hline & 0.9 & 2.3 & 15.2 & 22.9 & 15.2 & 2.8 & 0.8 & & 9.7 \\
\hline
\end{tabular}
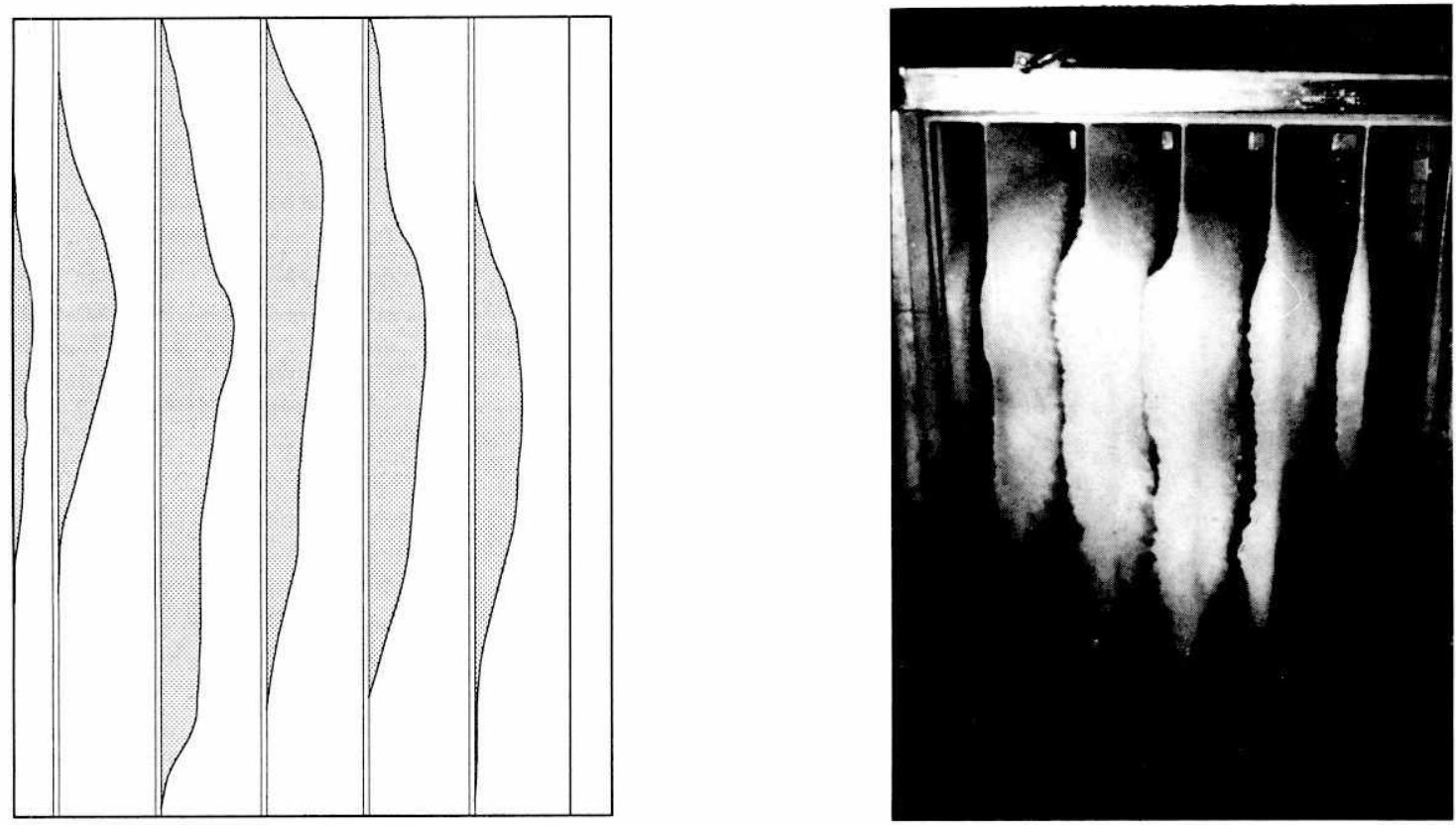

Figure C1. Icing of standard louver at the end of test 101. 
Table C2. Ice thickness in test 102.

\begin{tabular}{|c|c|c|c|c|c|c|c|c|c|}
\hline \multirow{2}{*}{$\begin{array}{c}\text { Elapsed } \\
\text { time } \\
\text { (hours) } \\
\end{array}$} & \multirow{2}{*}{$\begin{array}{l}\text { Dist. from } \\
\text { louver top } \\
\qquad(m)\end{array}$} & \multicolumn{7}{|c|}{ Ice thickness (mm) } & \multirow{2}{*}{$\begin{array}{c}\text { Average } \\
\text { accretion rate } \\
(\mathrm{mm} / \mathrm{hr})\end{array}$} \\
\hline & & Vane 1 & 2 & 3 & 4 & 5 & 6 & Average & \\
\hline \multirow[t]{3}{*}{1} & 0.3 & 2 & 19 & $<1$ & 19 & 11 & 3 & 12.5 & \\
\hline & 0.6 & $<1$ & 13 & 33 & 16 & 2 & 2 & 11.7 & \\
\hline & 0.9 & 2 & 4 & 38 & 1 & $<1$ & 2 & 7.9 & 10.7 \\
\hline \multirow[t]{3}{*}{2} & 0.3 & 6 & 35 & 41 & 48 & 26 & 3 & 26.2 & \\
\hline & 0.6 & 4 & 18 & 54 & 57 & 2 & $<1$ & 23.1 & \\
\hline & 0.9 & 2 & $<1$ & 52 & 36 & $<1$ & 2 & 16.2 & 11.2 \\
\hline \multirow[t]{3}{*}{3} & 0.3 & 14 & 53 & 80 & 61 & 27 & 4 & 39.4 & \\
\hline & 0.6 & 4 & 31 & 57 & 60 & 12 & 9 & 28.7 & \\
\hline & 0.9 & 2 & 9 & 59 & 79 & $<1$ & 1 & 24.9 & 9.1 \\
\hline \multirow[t]{7}{*}{4} & 0.3 & 24 & 88 & 90 & 67 & 42 & 8 & 53.1 & \\
\hline & 0.6 & 7 & 61 & 74 & 70 & 29 & 14 & 42.4 & \\
\hline & 0.9 & 1 & 16 & 89 & 61 & $<1$ & 3 & 28.2 & 10.2 \\
\hline & & \multicolumn{7}{|c|}{ Average ice accretion rates $(\mathrm{mm} / \mathrm{hr})$} & \\
\hline & 0.3 & 5.8 & 22.1 & 22.6 & 16.5 & 10.4 & 2.0 & & \\
\hline & 0.6 & 1.5 & 15.2 & 18.5 & 17.3 & 7.4 & 3.3 & & \\
\hline & 0.9 & 0.3 & 3.8 & 22.4 & 15.2 & 0 & 0.5 & & 10.4 \\
\hline
\end{tabular}
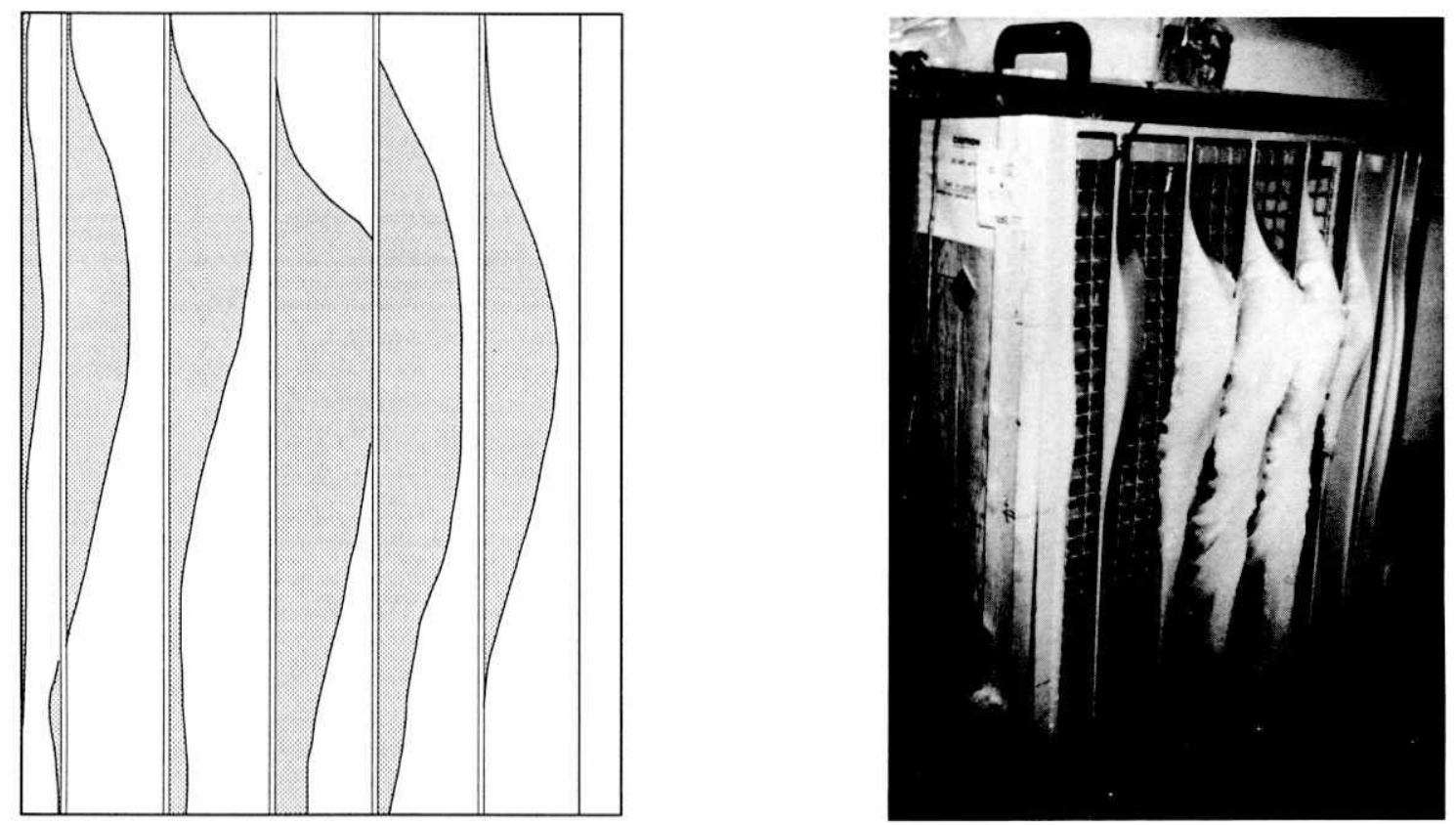

Figure C2. Icing of standard louver at the end of test 102. 
Table C3. Ice thickness in test 103.

\begin{tabular}{|c|c|c|c|c|c|c|c|c|c|}
\hline \multirow{2}{*}{$\begin{array}{l}\text { Elapsed } \\
\text { time } \\
\text { (hours) } \\
\end{array}$} & \multirow{2}{*}{$\begin{array}{l}\text { Dist. from } \\
\text { louver top } \\
(m)\end{array}$} & \multicolumn{7}{|c|}{ Ice thickness $(\mathrm{mm})$} & \multirow{2}{*}{$\begin{array}{c}\text { Average } \\
\text { accretion rate } \\
(\mathrm{mm} / \mathrm{hr})\end{array}$} \\
\hline & & Vane 1 & 2 & 3 & 4 & 5 & 6 & Average & \\
\hline \multirow[t]{3}{*}{1} & 0.3 & 2 & 4 & 6 & 4 & 2 & $<1$ & 3.1 & \\
\hline & 0.6 & 3 & 7 & 9 & 5 & 5 & 1 & 4.8 & \\
\hline & 0.9 & 5 & 13 & 13 & 12 & 4 & $<1$ & 7.9 & 5.3 \\
\hline \multirow[t]{3}{*}{2} & 0.3 & 7 & 16 & 14 & 9 & 3 & $<1$ & 8.1 & \\
\hline & 0.6 & 13 & 1 & 15 & 10 & 9 & 1 & 10.9 & \\
\hline & 0.9 & 16 & 29 & 25 & 24 & 7 & $<1$ & 16.8 & 6.6 \\
\hline \multirow[t]{7}{*}{3} & 0.3 & 10 & 20 & $<1$ & 20 & 5 & $<1$ & 12.7 & \\
\hline & 0.6 & 13 & 28 & 23 & 17 & 14 & 1 & 16.0 & \\
\hline & 0.9 & 19 & 36 & 39 & 35 & 6 & $<1$ & 0.9 & 5.1 \\
\hline & & \multicolumn{7}{|c|}{ Average ice accretion rates $(\mathrm{mm} / \mathrm{hr})$} & \\
\hline & 0.3 & 3.3 & 6.6 & 7.1 & 6.6 & 1.5 & 0.1 & & \\
\hline & 0.6 & 4.3 & 9.4 & 7.6 & 5.6 & 4.6 & 0.4 & & \\
\hline & 0.9 & 6.4 & 12.2 & 13.0 & 11.7 & 2.0 & 0.0 & & 5.6 \\
\hline
\end{tabular}
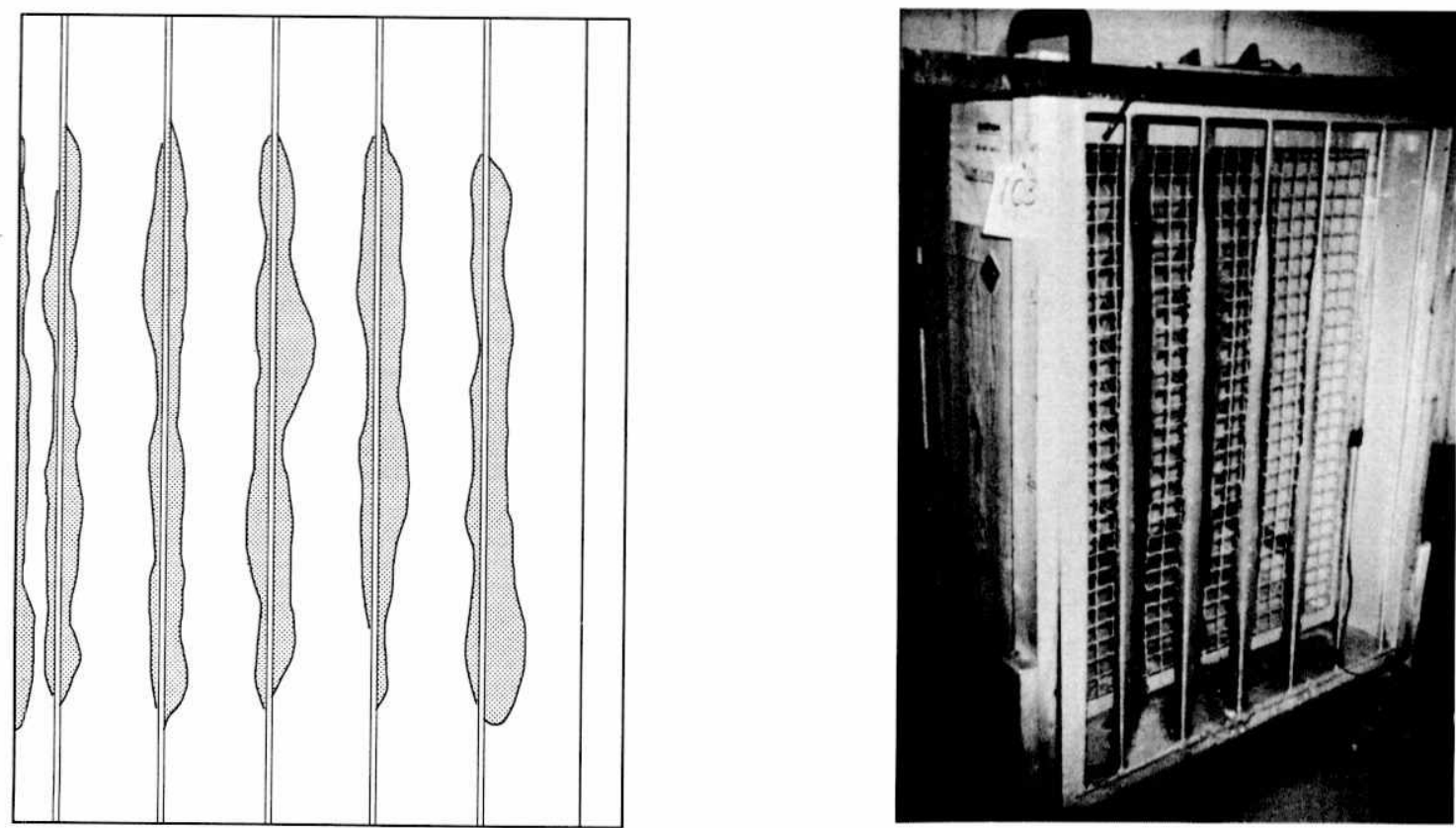

Figure C3. Icing of standard louver at the end of test 103. 
Table C4. Ice thickness in test 104.

\begin{tabular}{|c|c|c|c|c|c|c|c|c|c|}
\hline \multirow{2}{*}{$\begin{array}{l}\text { Elapsed } \\
\text { time } \\
\text { (hours) }\end{array}$} & \multirow{2}{*}{$\begin{array}{c}\text { Dist. from } \\
\text { louver top } \\
\quad(m)\end{array}$} & \multicolumn{7}{|c|}{ Ice thickness $(\mathrm{mm})$} & \multirow{2}{*}{$\begin{array}{c}\text { Average } \\
\text { accretion rate } \\
(\mathrm{mm} / \mathrm{hr})\end{array}$} \\
\hline & & Vane 1 & 2 & 3 & 4 & 5 & 6 & Average & \\
\hline \multirow[t]{3}{*}{1} & 0.3 & 16 & 15 & 17 & 17 & 14 & & 15.8 & \\
\hline & 0.6 & 24 & 27 & 19 & 29 & 40 & & 27.9 & \\
\hline & 0.9 & 10 & 20 & 32 & 46 & 28 & & 26.9 & 23.4 \\
\hline \multirow[t]{3}{*}{2} & 0.3 & 45 & 40 & 30 & 27 & 26 & & 33.5 & \\
\hline & 0.6 & 62 & 56 & 33 & 43 & 64 & & 51.6 & \\
\hline & 0.9 & 26 & 31 & 69 & 75 & 41 & & 48.3 & 20.8 \\
\hline \multirow[t]{7}{*}{3} & 0.3 & 60 & 53 & 43 & 38 & 32 & 36 & 43.4 & \\
\hline & 0.6 & 93 & 77 & 52 & 71 & 80 & & 74.8 & \\
\hline & 0.9 & 35 & 52 & 90 & 97 & 52 & 26 & 58.7 & 14.5 \\
\hline & & \multicolumn{7}{|c|}{ Average ice accretion rates $(\mathrm{mm} / \mathrm{hr})$. } & \\
\hline & 0.3 & 20.1 & 17.5 & 14.2 & 12.5 & 10.7 & 12.2 & & \\
\hline & 0.6 & 31.0 & 25.4 & 17.3 & 23.6 & 26.7 & & & \\
\hline & 0.9 & 11.7 & 17.3 & 30.2 & 32.5 & 17.5 & 8.64 & & 19.6 \\
\hline
\end{tabular}
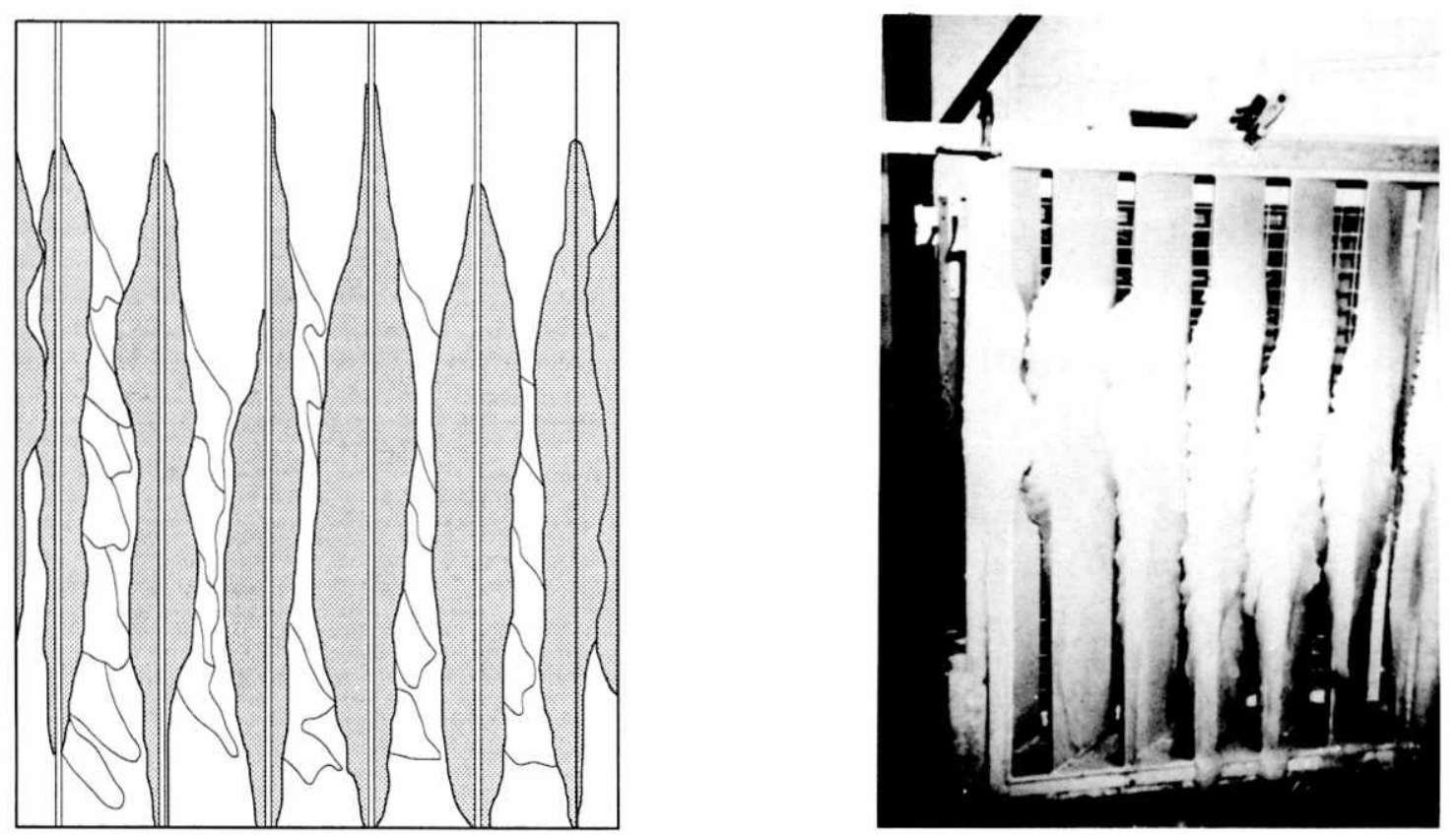

Figure C4. Icing of standard louver at the end of test 104. 
Table C5. Ice thickness in test 105.

\begin{tabular}{|c|c|c|c|c|c|c|c|c|c|}
\hline \multirow{2}{*}{$\begin{array}{l}\text { Elapsed } \\
\text { time } \\
\text { (hours) }\end{array}$} & \multirow{2}{*}{$\begin{array}{l}\text { Dist. from } \\
\text { louver top } \\
\text { (m) }\end{array}$} & \multicolumn{7}{|c|}{ Ice thickness ( $\mathrm{mm}$ ) } & \multirow{2}{*}{$\begin{array}{c}\text { Average } \\
\text { accretion rate } \\
(\mathrm{mm} / \mathrm{hr})\end{array}$} \\
\hline & & Vane 1 & 2 & 3 & 4 & 5 & 6 & Average & \\
\hline \multirow[t]{3}{*}{1} & 0.3 & $<1$ & $<1$ & $<1$ & $<1$ & $<1$ & & $<1$ & \\
\hline & 0.6 & $<1$ & 7 & 8 & 9 & 2 & & 5.1 & \\
\hline & 0.9 & $<1$ & 5 & 14 & 14 & $<1$ & & 6.6 & 3.8 \\
\hline \multirow[t]{3}{*}{2} & 0.3 & $<1$ & $<1$ & 2 & 3 & $<1$ & & 1.3 & \\
\hline & 0.6 & $<1$ & 8 & 26 & 21 & 2 & & 11.4 & \\
\hline & 0.9 & $<1$ & 4 & 21 & 18 & $<1$ & & 8.6 & 3.0 \\
\hline \multirow[t]{3}{*}{3} & 0.3 & $<1$ & 3 & 6 & 10 & 3 & & 4.1 & \\
\hline & 0.6 & 0 & 11 & 33 & 43 & 4 & & 18.3 & \\
\hline & 0.9 & $<1$ & 6 & 12 & 24 & $<1$ & & 7.9 & 3.0 \\
\hline \multirow[t]{7}{*}{4} & 0.3 & $<1$ & 3 & 6 & 10 & 3 & & 4.1 & \\
\hline & 0.6 & 0 & 13 & 51 & 55 & 7 & & 25.4 & \\
\hline & 0.9 & $<1$ & 4 & 38 & 33 & $<1$ & & 15.0 & 4.8 \\
\hline & & \multicolumn{7}{|c|}{ Average ice accretion rates $(\mathrm{mm} / \mathrm{hr})$} & \\
\hline & 0.3 & 0.0 & 0.8 & 1.3 & 2.3 & 0.8 & & & \\
\hline & 0.6 & 0.0 & 3.3 & 13.0 & 13.7 & 1.8 & & & \\
\hline & 0.9 & 0.0 & 1.0 & 9.7 & 8.1 & 0.0 & & & 3.6 \\
\hline
\end{tabular}
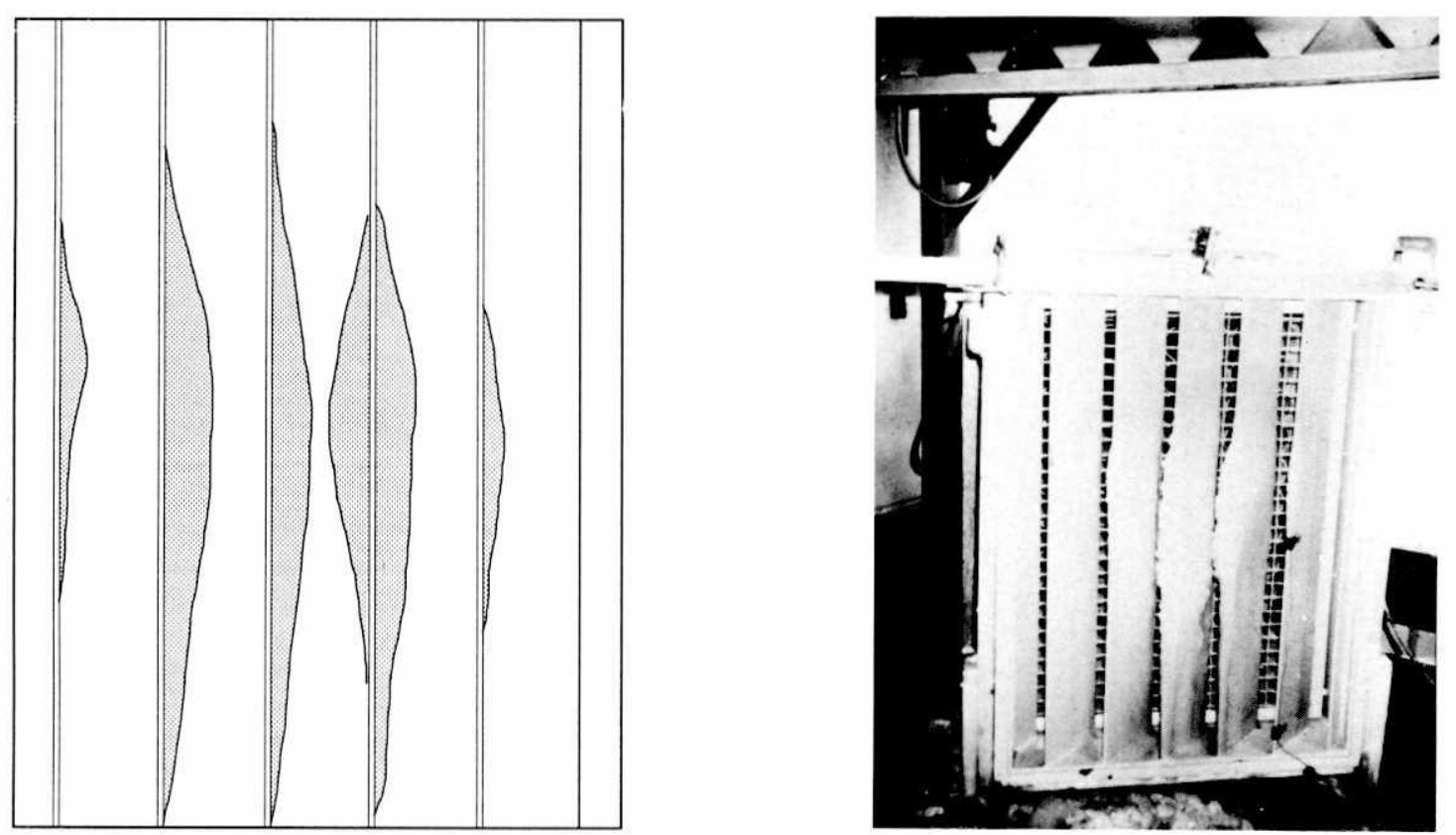

Figure C5. Icing of standard louver at the end of test 105. 
Table C6. Ice thickness in test $\mathbf{1 0 6 .}$

\begin{tabular}{|c|c|c|c|c|c|c|c|c|c|}
\hline \multirow{2}{*}{$\begin{array}{l}\text { Elapsed } \\
\text { time } \\
\text { (hours) }\end{array}$} & \multirow{2}{*}{$\begin{array}{l}\text { Dist. from } \\
\text { louver top } \\
\text { (m) }\end{array}$} & \multicolumn{7}{|c|}{ Ice thickness $(\mathrm{mm})$} & \multirow{2}{*}{$\begin{array}{c}\text { Average } \\
\text { accretion rate } \\
(\mathrm{mm} / \mathrm{hr})\end{array}$} \\
\hline & & Vane 1 & 2 & 3 & 4 & 5 & 6 & Average & \\
\hline \multirow[t]{3}{*}{1} & 0.3 & 2.0 & 13 & 17 & 16 & 12 & & 11.7 & \\
\hline & 0.6 & 1.5 & 9 & 24 & 15 & 16 & & 13.0 & \\
\hline & 0.9 & $<1$ & 3 & 26 & 25 & 17 & & 14.0 & 13.0 \\
\hline \multirow[t]{3}{*}{2} & 0.3 & 10 & 27 & 27 & 28 & 19 & & 21.8 & \\
\hline & 0.6 & 11 & 33 & 60 & 42 & 15 & & 32.0 & \\
\hline & 0.9 & 18 & 26 & 40 & 32 & 25 & & 27.9 & 14.5 \\
\hline \multirow[t]{3}{*}{3} & 0.3 & 17 & 33 & 38 & 36 & 27 & & 30.2 & \\
\hline & 0.6 & 21 & 50 & 68 & 33 & 36 & & 41.7 & \\
\hline & 0.9 & 23 & 38 & 46 & 40 & 23 & & 33.8 & 7.9 \\
\hline \multirow[t]{7}{*}{4} & 0.3 & 17 & 47 & 47 & 46 & 33 & & 37.9 & \\
\hline & 0.6 & 23. & 59 & 78 & 45 & 33 & & 47.5 & \\
\hline & 0.9 & 21 & 41 & 65 & 55 & 37 & & 43.4 & 7.6 \\
\hline & & \multicolumn{7}{|c|}{ Average ice accretion rates $(\mathrm{mm} / \mathrm{hr})$} & \\
\hline & 0.3 & 4.1 & 11.7 & 11.7 & 11.4 & 8.4 & & & \\
\hline & 0.6 & 5.8 & 14.7 & 19.6 & 11.2 & 8.1 & & & \\
\hline & 0.9 & 5.1 & 10.2 & 16.0 & 13.7 & 9.1 & & & 9.7 \\
\hline
\end{tabular}
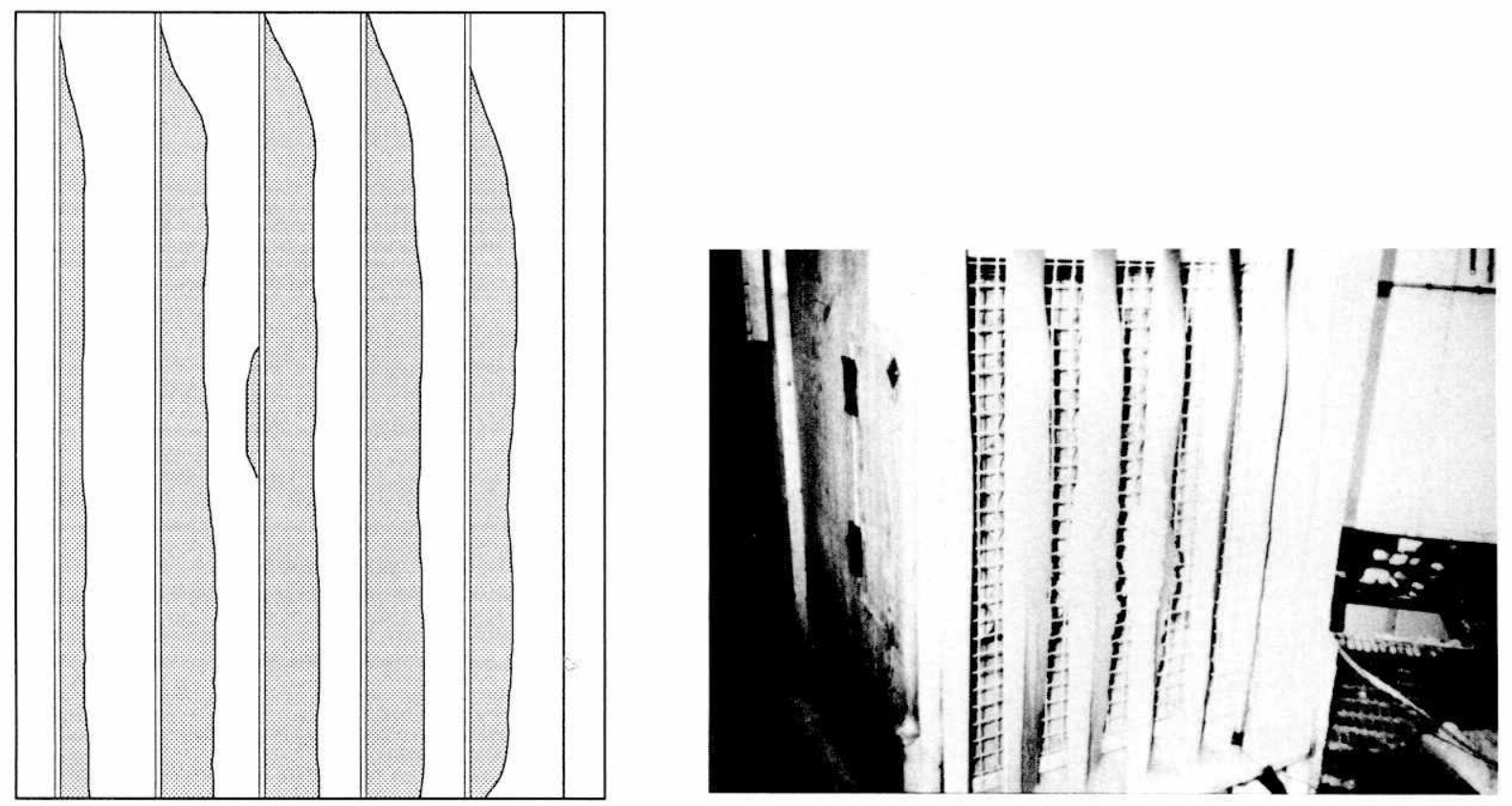

Figure C6. Icing of standard louver at the end of test 106. 
Table C7. Ice thickness in test 107.

\begin{tabular}{|c|c|c|c|c|c|c|c|c|c|}
\hline \multirow{2}{*}{$\begin{array}{l}\text { Elapsed } \\
\text { time } \\
\text { (hours) }\end{array}$} & \multirow{2}{*}{$\begin{array}{l}\text { Dist. from } \\
\text { louver top } \\
(m)\end{array}$} & \multicolumn{7}{|c|}{ Ice thickness (mm) } & \multirow{2}{*}{$\begin{array}{c}\text { Average } \\
\text { accretion rate } \\
(\mathrm{mm} / \mathrm{hr})\end{array}$} \\
\hline & & Vane 1 & 2 & 3 & 4 & 5 & 6 & Average & \\
\hline \multirow[t]{3}{*}{1} & 0.3 & $<1$ & 2 & 4 & 5 & 2 & & 2.3 & \\
\hline & 0.6 & 4 & 6 & 6 & 6 & 6 & & 5.6 & \\
\hline & 0.9 & 1 & 5 & 5 & 4 & 5 & & 3.9 & 3.8 \\
\hline \multirow[t]{3}{*}{2} & 0.3 & $<1$ & 2 & 5 & 8 & 4 & & 3.9 & \\
\hline & 0.6 & 9 & 12 & 9 & 11 & 10 & & 9.9 & \\
\hline & 0.9 & 5 & 10 & 7 & 7 & 9 & & 7.6 & 3.3 \\
\hline \multirow[t]{3}{*}{3} & 0.3 & $<1$ & 3 & 11 & 16 & 5 & & 7.1 & \\
\hline & 0.6 & 15 & 22 & 18 & 19 & 15 & & 17.8 & \\
\hline & 0.9 & 3 & 21 & 9 & 13 & 13 & & 11.7 & \\
\hline \multirow[t]{7}{*}{4} & 0.3 & $<1$ & 4 & 17 & 23 & 7 & & 9.9 & \\
\hline & 0.6 & 20 & 32 & 26 & 21 & 18 & & 24.1 & \\
\hline & 0.9 & 3 & 27 & 13 & 19 & 16 & & 15.2 & 4.3 \\
\hline & & \multicolumn{7}{|c|}{ Average ice accretion rates $(\mathrm{mm} / \mathrm{hr})$} & \\
\hline & 0.3 & 0.0 & 1.0 & 4.3 & 5.6 & 1.5 & & & \\
\hline & 0.6 & 5.1 & 8.1 & 6.4 & 6.4 & 4.6 & & & \\
\hline & 0.9 & 0.8 & 6.6 & 3.1 & 4.6 & 3.8 & & & 3.8 \\
\hline
\end{tabular}
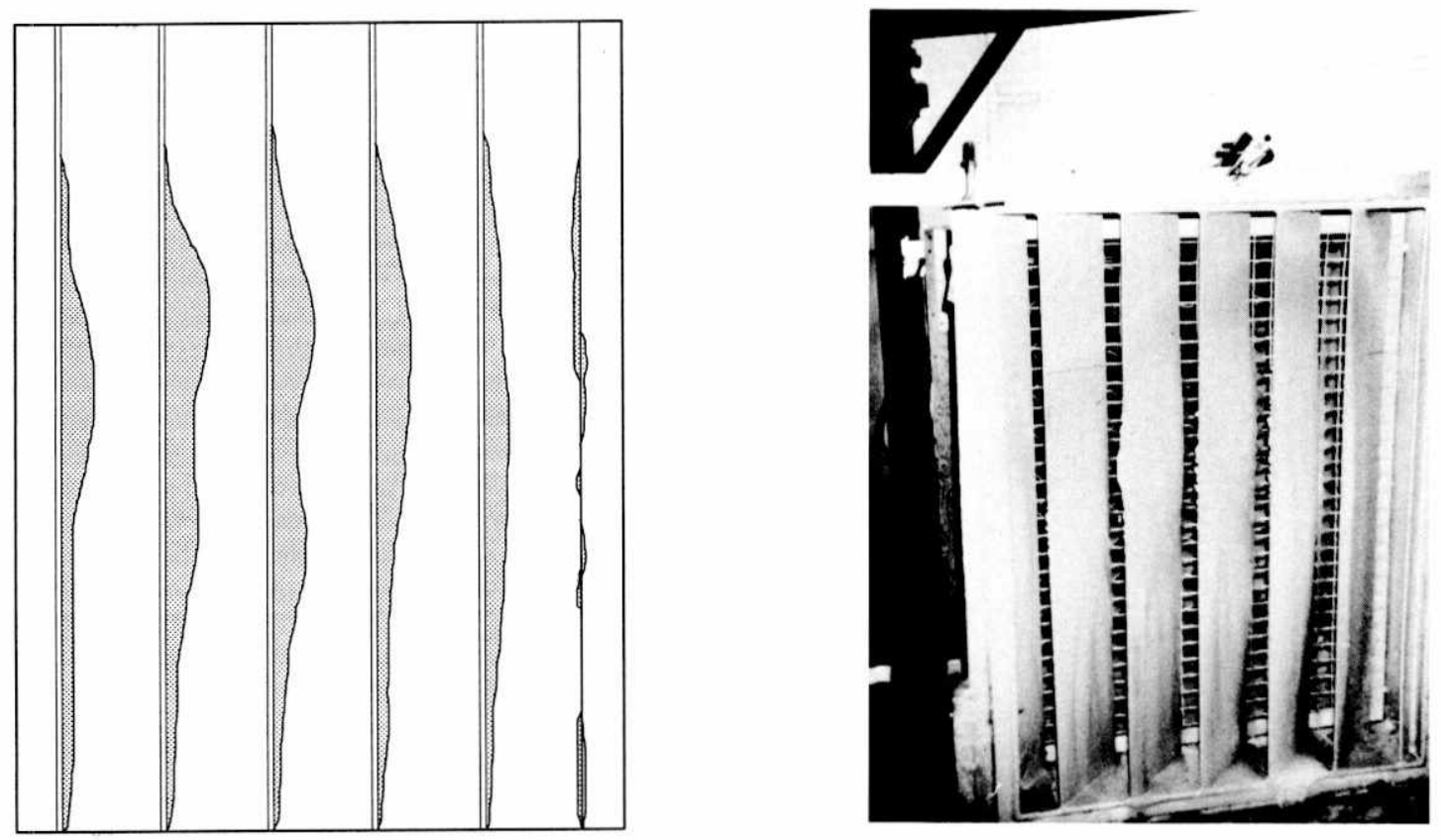

Figure C7. Icing of standard louver at the end of test 107. 
Table C8. Ice thickness in test 108.

\begin{tabular}{|c|c|c|c|c|c|c|c|c|c|}
\hline \multirow{2}{*}{$\begin{array}{l}\text { Elapsed } \\
\text { time } \\
\text { (hours) }\end{array}$} & \multirow{2}{*}{$\begin{array}{l}\text { Dist. from } \\
\text { louver top } \\
\quad(m)\end{array}$} & \multicolumn{7}{|c|}{ Ice thickness $(\mathrm{mm})$} & \multirow{2}{*}{$\begin{array}{c}\text { Average } \\
\text { accretion rate } \\
(\mathrm{mm} / \mathrm{hr})\end{array}$} \\
\hline & & Vane 1 & 2 & 3 & 4 & 5 & 6 & Average & \\
\hline \multirow[t]{3}{*}{1} & 0.3 & 12 & 28 & 35 & 30 & 20 & 10 & 22.4 & \\
\hline & 0.6 & 3 & 38 & 41 & 49 & 64 & 19 & 35.6 & \\
\hline & 0.9 & $<1$ & 12 & 37 & 38 & 19 & 23 & 21.6 & 26.4 \\
\hline \multirow[t]{7}{*}{2} & 0.3 & 19 & 30 & 47 & 48 & 32 & 22 & 32.8 & \\
\hline & 0.6 & 26 & 81 & 64 & 53 & 79 & 16 & 53.1 & \\
\hline & 0.9 & $<1$ & 23 & 70 & 75 & 48 & 40 & 42.4 & 16.3 \\
\hline & & \multicolumn{7}{|c|}{ Average ice accretion rates $(\mathrm{mm} / \mathrm{hr})$} & \\
\hline & 0.3 & 4.8 & 14.7 & 23.4 & 23.9 & 16.0 & 10.9 & & \\
\hline & 0.6 & 6.4 & 40.4 & 31.8 & 26.4 & 39.6 & 8.1 & & \\
\hline & 0.9 & 0.00 & 11.2 & 35.1 & 37.3 & 23.9 & 19.8 & & 21.8 \\
\hline
\end{tabular}
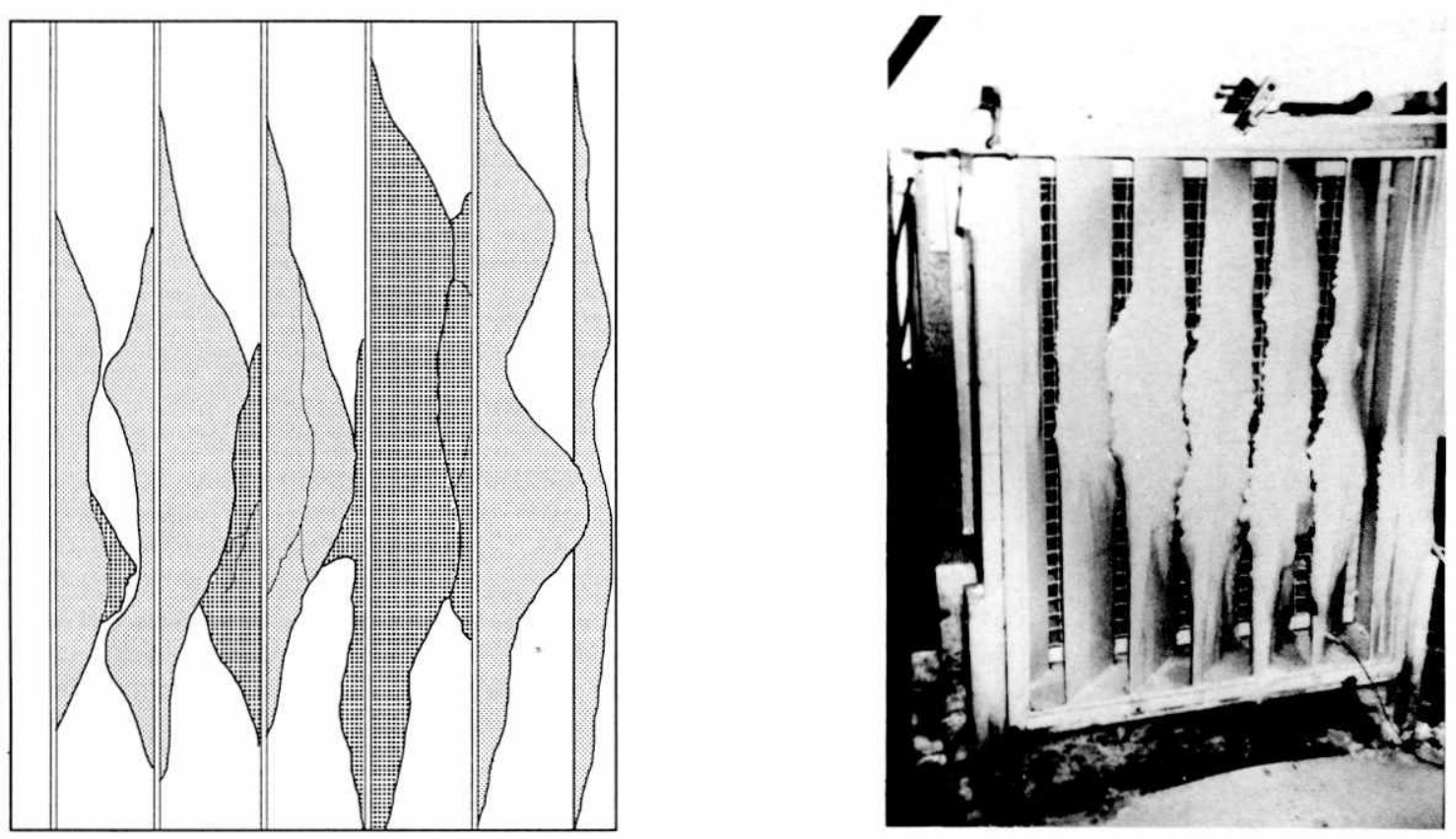

Figure C8. Icing of standard louver at the end of test 108. 
Table C9. Ice thickness in test 201.

\begin{tabular}{|c|c|c|c|c|c|c|c|c|c|c|c|c|c|}
\hline \multirow{2}{*}{$\begin{array}{c}\text { Elapsed } \\
\text { time } \\
\text { (hours) }\end{array}$} & \multirow{2}{*}{$\begin{array}{l}\text { Dist. from } \\
\text { louver top } \\
\quad(m)\end{array}$} & \multicolumn{11}{|c|}{ Ice thickness (mm) } & \multirow{2}{*}{$\begin{array}{c}\text { Average } \\
\text { accretion rate } \\
(\mathrm{mm} / \mathrm{hr})\end{array}$} \\
\hline & & Vane 1 & 2 & 3 & 4 & 5 & 6 & 7 & 8 & 9 & 10 & Average & \\
\hline \multirow[t]{3}{*}{1} & 0.3 & 2 & 8 & 13 & 18 & 16 & 14 & 15 & 12 & 5 & $<1$ & 10.2 & 9.9 \\
\hline & 0.6 & 5 & 9 & 10 & 11 & 10 & 10 & 10 & 14 & 11 & 4 & 9.4 & \\
\hline & 0.9 & $<1$ & 1 & 4 & 15 & 25 & 24 & 18 & 10 & 5 & $<1$ & 10.2 & \\
\hline \multirow[t]{3}{*}{2} & 0.3 & 4 & 14 & 21 & 27 & 36 & 26 & 30 & 26 & 14 & 5 & 20.1 & 8.6 \\
\hline & 0.6 & 9 & 16 & 18 & 23 & 20 & 16 & 21 & 25 & 21 & 9 & 17.5 & \\
\hline & 0.9 & 1 & 2 & 9 & 30 & 38 & 35 & 34 & 23 & 6 & 1 & 17.8 & \\
\hline \multirow[t]{3}{*}{3} & 0.3 & $<1$ & 27 & 36 & 46 & 76 & 76 & 35 & 28 & 16 & 5 & 35.6 & 9.9 \\
\hline & 0.6 & 10 & 24 & 39 & 37 & 24 & 26 & 30 & 28 & 24 & 35 & 27.7 & \\
\hline & 0.9 & 2 & 7 & 20 & 47 & 41 & 39 & 34 & 24 & 5 & 2 & 22.1 & \\
\hline \multirow[t]{7}{*}{4} & 0.3 & 24 & 44 & 76 & 76 & 76 & 76 & 76 & 76 & 17 & 8 & 55.1 & 14.7 \\
\hline & 0.6 & 21 & 38 & 41 & 44 & 32 & 28 & 34 & 76 & 76 & 23 & 41.4 & \\
\hline & 0.9 & 4 & 27 & 46 & 57 & 76 & 41 & 35 & 32 & 8 & 2 & 32.8 & \\
\hline & & \multicolumn{11}{|c|}{ Average ice accretion rates $(\mathrm{mm} / \mathrm{hr})$} & \\
\hline & 0.3 & 6.1 & 10.9 & 19.0 & 19.0 & 19.0 & 19.0 & 19.0 & 19.0 & 4.1 & 2.0 & & \\
\hline & 0.6 & 5.3 & 9.7 & 10.4 & 10.9 & 7.9 & 6.9 & 8.4 & 19.0 & 19.0 & 5.8 & & \\
\hline & 0.9 & 1.0 & 6.6 & 11.4 & 14.2 & 19.0 & 10.2 & 8.6 & 7.9 & 2.0 & 0.3 & & 10.7 \\
\hline
\end{tabular}
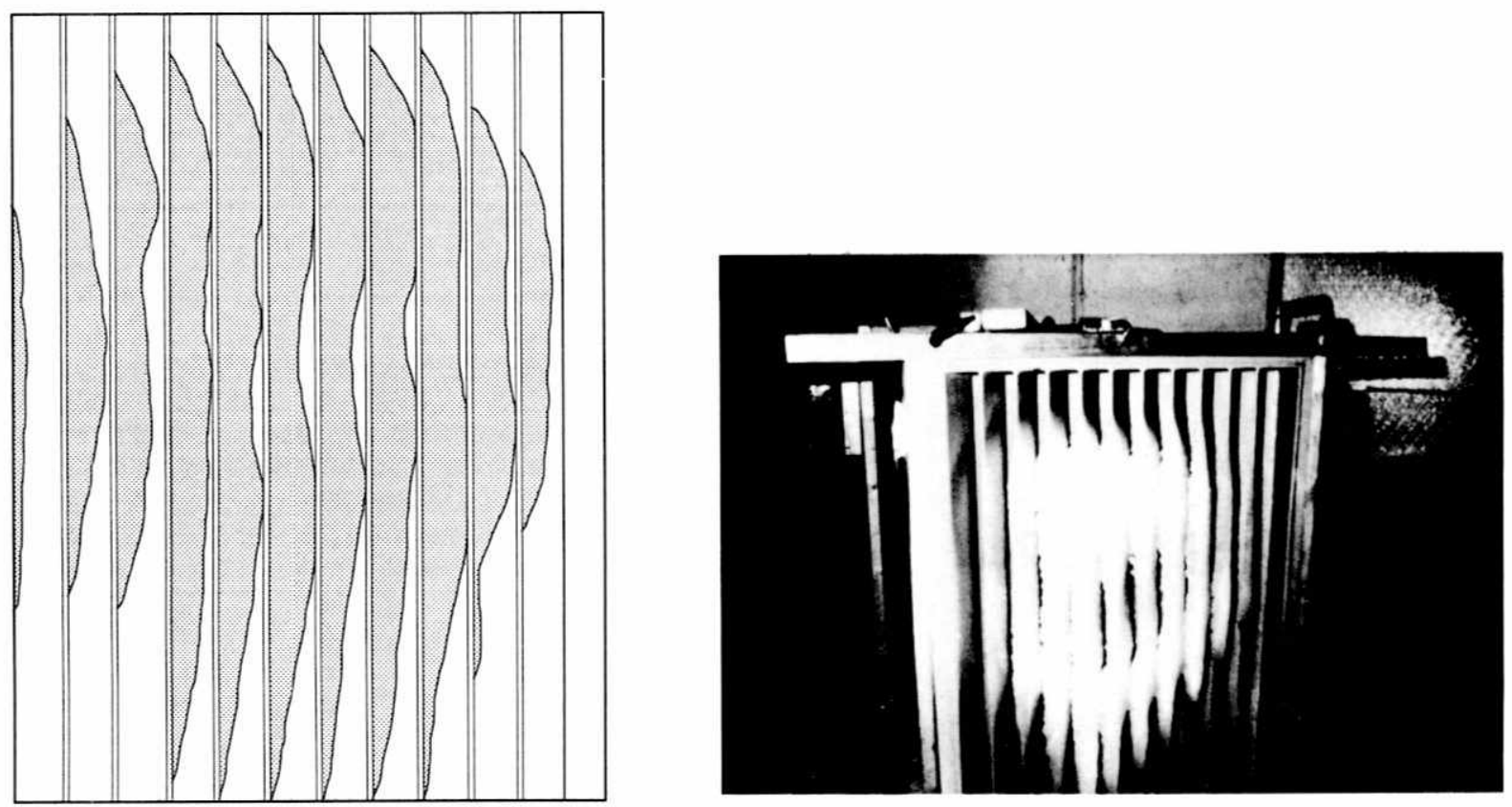

Figure C9. Icing of prototype louver at the end of test 201. 
Table C10. Ice thickness in test 202.

\begin{tabular}{|c|c|c|c|c|c|c|c|c|c|c|c|c|c|}
\hline \multirow{2}{*}{$\begin{array}{c}\text { Elapsed } \\
\text { time } \\
\text { (hours) }\end{array}$} & \multirow{2}{*}{$\begin{array}{l}\text { Dist. from } \\
\text { louver top } \\
\qquad(m)\end{array}$} & \multicolumn{11}{|c|}{ Ice thickness $(\mathrm{mm})$} & \multirow{2}{*}{$\begin{array}{c}\text { Average } \\
\text { accretion rate } \\
(\mathrm{mm} / \mathrm{hr})\end{array}$} \\
\hline & & Vane 1 & 2 & 3 & 4 & 5 & 6 & 7 & 8 & 9 & 10 & Average & \\
\hline \multirow[t]{3}{*}{1} & 0.3 & 19 & 25 & 29 & 32 & 25 & 25 & 24 & 17 & 6 & 3 & 20.3 & 10.9 \\
\hline & 0.6 & 3 & 3 & 5 & 7 & 7 & 8 & 13 & 13 & 12 & 7 & 7.6 & \\
\hline & 0.9 & 5 & 5 & 3 & 2 & 1 & 2 & 2 & 6 & 10 & 12 & 4.6 & \\
\hline \multirow[t]{3}{*}{2} & 0.3 & 35 & 43 & 76 & 76 & 76 & 36 & 35 & 21 & 35 & 3 & 43.4 & 12.4 \\
\hline & 0.6 & 4 & 6 & 17 & 25 & 20 & 29 & 25 & 23 & 17 & 14 & 17.8 & \\
\hline & 0.9 & 10 & 11 & 5 & 2 & 2 & 3 & 6 & 16 & 21 & 7 & 8.1 & \\
\hline \multirow[t]{3}{*}{3} & 0.3 & 59 & 76 & 76 & 76 & 76 & 76 & 76 & 76 & 23 & 6 & 62.2 & 11.7 \\
\hline & 0.6 & 8 & 16 & 39 & 39 & 41 & 37 & 35 & 26 & 19 & 15 & 27.4 & \\
\hline & 0.9 & 14 & 16 & 16 & 10 & 16 & 24 & 6 & 14 & 18 & 17 & 14.7 & \\
\hline \multirow[t]{7}{*}{4} & 0.3 & 67 & 76 & 76 & 76 & 76 & 76 & 76. & 76 & 23 & 7 & 63.0 & 6.1 \\
\hline & 0.6 & 14 & 37 & 38 & 76 & 50 & 40 & 38 & 33 & 24 & 17 & 36.6 & \\
\hline & 0.9 & 14 & 21 & 28 & 36 & 31 & 41 & 8 & 17 & 21 & 17 & 23.4 & \\
\hline & & \multicolumn{11}{|c|}{ Average ice accretion rates $(\mathrm{mm} / \mathrm{hr})$} & \\
\hline & 0.3 & 16.8 & 19.0 & 19.0 & 19.0 & 19.0 & 19.0 & 19.0 & 19.0 & 5.8 & 1.8 & & \\
\hline & 0.6 & 3.3 & 9.1 & 9.4 & 19.0 & 12.4 & 9.9 & 9.4 & 8.1 & 5.8 & 4.3 & & \\
\hline & 0.9 & 3.6 & 5.3 & 6.9 & 8.9 & 7.9 & 10.4 & 2.0 & 4.1 & 5.1 & 4.3 & & 10.2 \\
\hline
\end{tabular}
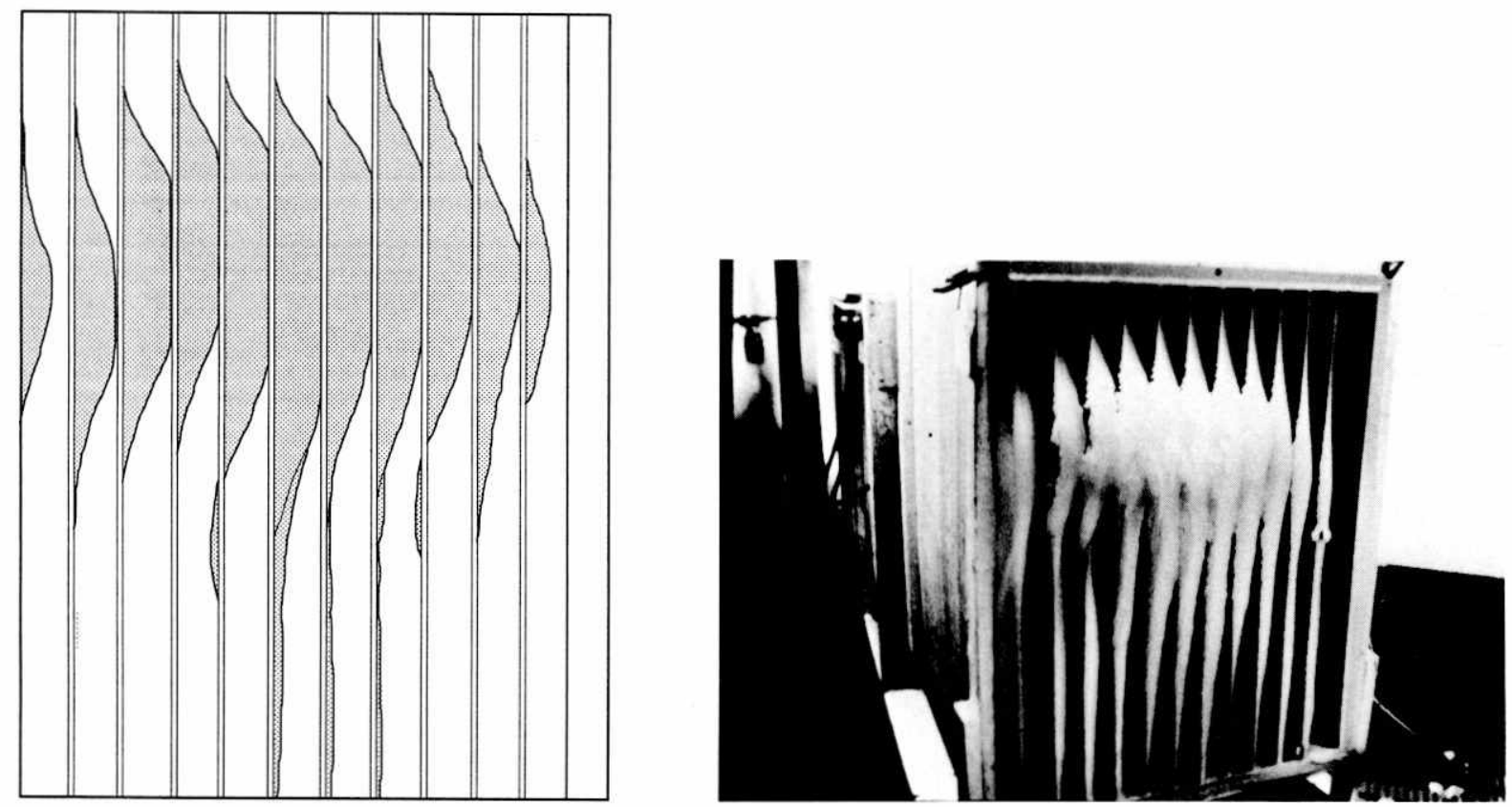

Figure C10. Icing of prototype louver at the end of test 202. 
Table C11. Ice thickness in test 203.

\begin{tabular}{|c|c|c|c|c|c|c|c|c|c|c|c|c|c|}
\hline \multirow{2}{*}{$\begin{array}{l}\text { Elapsed } \\
\text { time } \\
\text { (hours) } \\
\end{array}$} & \multirow{2}{*}{$\begin{array}{l}\text { Dist. from } \\
\text { louver top } \\
\quad(m)\end{array}$} & \multicolumn{11}{|c|}{ Ice thickness $(\mathrm{mm})$} & \multirow{2}{*}{$\begin{array}{c}\text { Average } \\
\text { accretion rate } \\
(\mathrm{mm} / \mathrm{hr})\end{array}$} \\
\hline & & Vane 1 & 2 & 3 & 4 & 5 & 6 & 7 & 8 & 9 & 10 & Average & \\
\hline \multirow[t]{3}{*}{1} & 0.3 & 3 & 5 & 8 & 10 & 10 & 8 & 8 & 8 & 6 & 3 & 6.9 & 6.9 \\
\hline & 0.6 & 4 & 7 & 9 & 12 & 10 & 7 & 8 & 7 & 6 & 5 & 7.4 & \\
\hline & 0.9 & $<1$ & 4 & 7 & 10 & 11 & 11 & 10 & 8 & 2 & $<1$ & 6.4 & \\
\hline \multirow[t]{3}{*}{2} & 0.3 & 6 & 11 & 18 & 19 & 19 & 12 & 13 & 14 & 12 & 10 & 13.2 & 5.6 \\
\hline & 0.6 & 10 & 13 & 18 & 19 & 17 & 11 & 11 & 15 & 10 & 7 & 13.2 & \\
\hline & 0.9 & 4 & 7 & 11 & 20 & 23 & 22 & 16 & 8 & 2 & $<1$ & 11.2 & \\
\hline \multirow[t]{7}{*}{3} & 0.3 & 9 & 17 & 22 & 25 & 25 & 20 & 18 & 24 & 18 & 10 & 18.5 & 6.6 \\
\hline & 0.6 & 16 & 21 & 25 & 28 & 24 & 18 & 20 & 25 & 18 & 14 & 20.6 & \\
\hline & 0.9 & 8 & 15 & 22 & 23 & 33 & 32 & 26 & 18 & 4 & 4 & 18.3 & \\
\hline & & \multicolumn{11}{|c|}{ Average ice accretion rates $(\mathrm{mm} / \mathrm{hr})$} & \\
\hline & 0.3 & 3.1 & 5.6 & 7.4 & 8.4 & 8.4 & 6.6 & 5.8 & 7.9 & 6.1 & 3.3 & & \\
\hline & 0.6 & 5.3 & 7.1 & 8.4 & 9.1 & 8.1 & 5.8 & 6.9 & 8.4 & 5.8 & 4.6 & & \\
\hline & 0.9 & 2.8 & 5.1 & 7.4 & 7.6 & 10.9 & 10.7 & 8.6 & 5.8 & 1.3 & 1.3 & & 6.4 \\
\hline
\end{tabular}
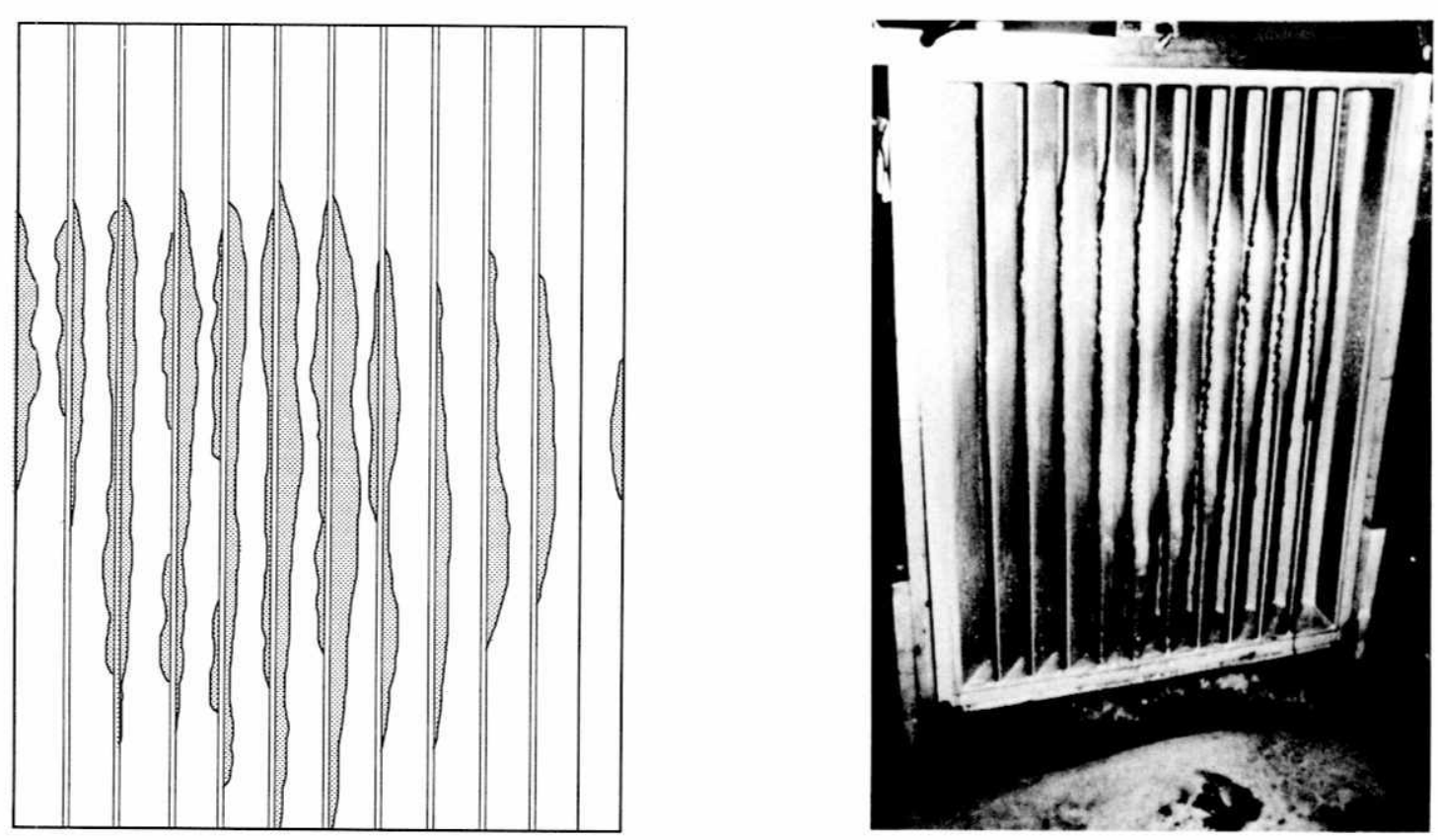

Figure C11. Icing of prototype louver at the end of test 203. 
Table C12. Ice thickness in test 204.

\begin{tabular}{|c|c|c|c|c|c|c|c|c|c|c|c|c|c|}
\hline \multirow{2}{*}{$\begin{array}{c}\text { Elapsed } \\
\text { time } \\
\text { (hours) }\end{array}$} & \multirow{2}{*}{$\begin{array}{c}\text { Dist. from } \\
\text { louver top } \\
(\mathrm{m})\end{array}$} & \multicolumn{11}{|c|}{ Ice thickness $(\mathrm{mm})$} & \multirow{2}{*}{$\begin{array}{c}\text { Average } \\
\text { accretion rate } \\
(\mathrm{mm} / \mathrm{hr})\end{array}$} \\
\hline & & Vane 1 & 2 & 3 & 4 & 5 & 6 & 7 & 8 & 9 & 10 & Average & \\
\hline \multirow[t]{3}{*}{1} & 0.3 & 4 & 7 & 10 & 19 & 20 & 18 & 19 & 19 & 19 & 10 & 14.5 & 22.1 \\
\hline & 0.6 & 19 & 26 & 24 & 28 & 26 & 31 & 30 & 27 & 11 & 31 & 25.1 & \\
\hline & 0.9 & 29 & 40 & 38 & 34 & 34 & 34 & 26 & 15 & $<1$ & 16 & 26.7 & \\
\hline \multirow[t]{3}{*}{2} & 0.3 & 7 & 12 & 20 & 24 & 25 & 25 & 24 & 19 & 19 & 14 & 18.8 & 9.7 \\
\hline & 0.6 & 28 & 44 & 37 & 39 & 38 & 36 & 41 & 36 & 33 & 49 & 38.1 & \\
\hline & 0.9 & 38 & 54 & 47 & 48 & 48 & 42 & 39 & 39 & 14 & 25 & 38.9 & \\
\hline \multirow[t]{7}{*}{3} & 0.3 & 9 & 23 & 42 & 76 & 76 & 76 & 76 & 76 & 76 & 76 & 60.7 & 27.4 \\
\hline & 0.6 & 58 & 76 & 76 & 76 & 76 & 76 & 49 & 51 & 40 & 64 & 64.3 & \\
\hline & 0.9 & 66 & 58 & 45 & 56 & 47 & 63 & 45 & 48 & 58 & 42 & 52.6 & \\
\hline & & \multicolumn{11}{|c|}{ Average ice accretion rates $(\mathrm{mm} / \mathrm{hr})$} & \\
\hline & 0.3 & 3.1 & 7.6 & 14.0 & 25.4 & 25.4 & 25.4 & 25.4 & 25.4 & 25.4 & 25.4 & & \\
\hline & 0.6 & 19.6 & 25.4 & 25.4 & 25.4 & 25.4 & 25.4 & 16.3 & 16.8 & 13.2 & 21.3 & & \\
\hline & 0.9 & 21.8 & 19.3 & 15.0 & 18.5 & 15.7 & 21.1 & 15.0 & 16.0 & 19.3 & 14.0 & & 19.8 \\
\hline
\end{tabular}
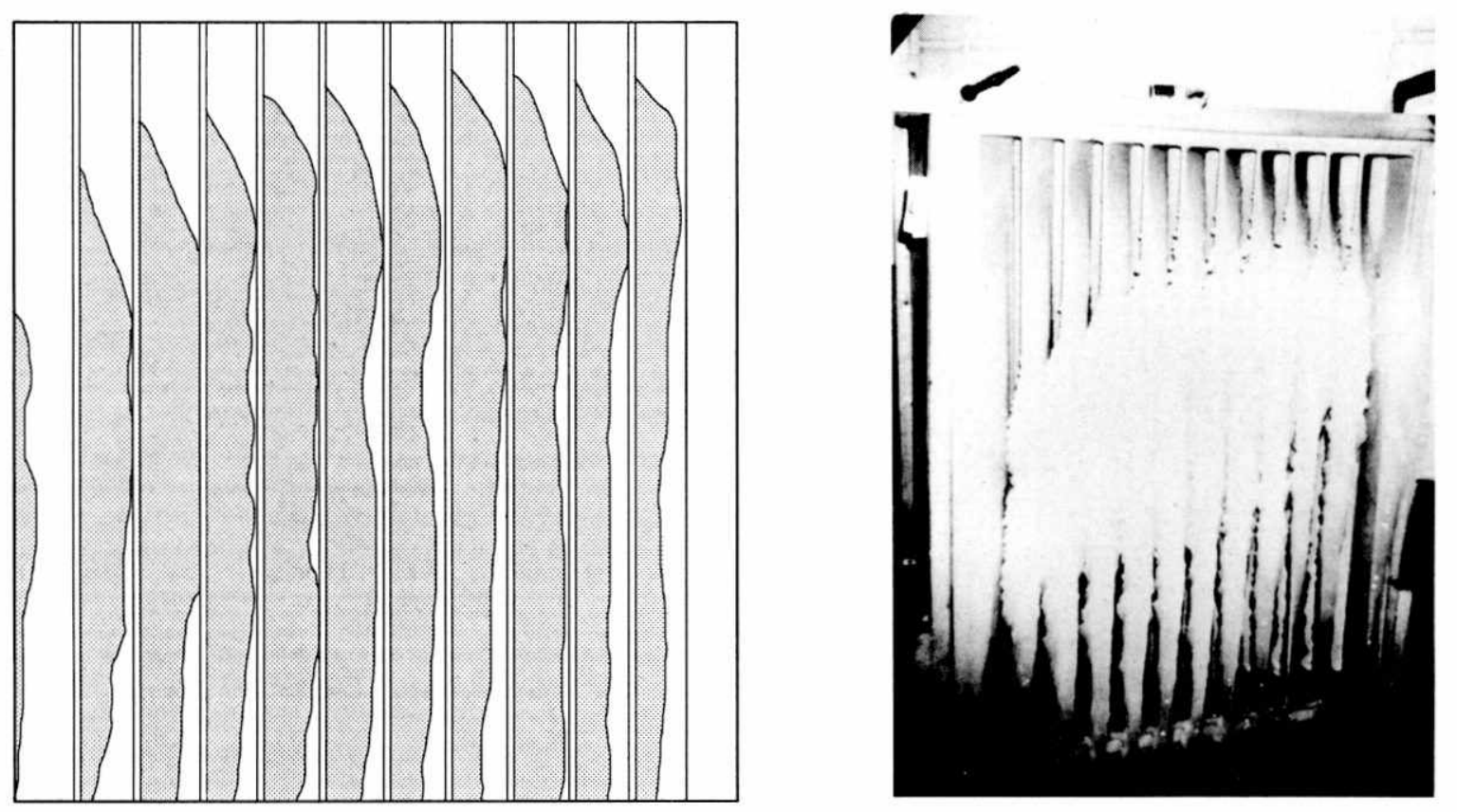

Figure C12. Icing of prototype louver at the end of test 204. 
Table C13. Ice thickness in test 205.

\begin{tabular}{|c|c|c|c|c|c|c|c|c|c|c|c|c|c|}
\hline \multirow{2}{*}{$\begin{array}{l}\text { Elapsed } \\
\text { time } \\
\text { (hours) }\end{array}$} & \multirow{2}{*}{$\begin{array}{l}\text { Dist. from } \\
\text { louver top } \\
\qquad(\mathrm{m})\end{array}$} & \multicolumn{11}{|c|}{ Ice thickness $(\mathrm{mm})$} & \multirow{2}{*}{$\begin{array}{c}\text { Average } \\
\text { accretion rate } \\
(\mathrm{mm} / \mathrm{hr})\end{array}$} \\
\hline & & Vane 1 & 2 & 3 & 4 & 5 & 6 & 7 & 8 & 9 & 10 & Average & \\
\hline \multirow[t]{3}{*}{1} & 0.3 & $<1$ & 2 & 4 & 8 & 11 & 14 & 13 & 5 & 3 & 1 & 6.1 & 5.3 \\
\hline & 0.6 & $<1$ & $<1$ & $<1$ & 9 & 16 & 22 & 22 & 15 & 3 & $<1$ & 8.6 & \\
\hline & 0.9 & $<1$ & 1 & $<1$ & $<1$ & 3 & 6 & 4 & $<1$ & $<1$ & $<1$ & 1.5 & \\
\hline \multirow[t]{3}{*}{2} & 0.3 & $<1$ & 3 & 5 & 8 & 16 & 19 & 15 & 6 & 4 & 2 & 7.6 & 3.1 \\
\hline & 0.6 & $<1$ & $<1$ & 1 & 11 & 22 & 30 & 33 & 22 & 6 & $<1$ & 12.4 & \\
\hline & 0.9 & $<1$ & $<1$ & $<1$ & $<1$ & 6 & 26 & 16 & 4 & $<1$ & $<1$ & 5.3 & \\
\hline \multirow[t]{3}{*}{3} & 0.3 & $<1$ & 2 & 5 & 9 & 19 & 19 & 14 & 6 & 4 & 2 & 7.9 & 2.8 \\
\hline & 0.6 & $<1$ & 0 & 2 & 13 & 30 & 36 & 39 & 26 & 9 & $<1$ & 15.7 & \\
\hline & 0.9 & $<1$ & $<1$ & 2 & 5 & 16 & 37 & 30 & 13 & $<1$ & $<1$ & 10.4 & \\
\hline \multirow[t]{7}{*}{4} & 0.3 & $<1$ & 2 & 4 & 8 & 16 & 21 & 24 & 7 & 4 & 3 & 8.9 & 2.0 \\
\hline & 0.6 & $<1$ & $<1$ & 2 & 15 & 38 & 42 & 43 & 29 & 12 & 1 & 18.3 & \\
\hline & 0.9 & $<1$ & $<1$ & 2 & 6 & 19 & 43 & 42 & 18 & $<1$ & $<1$ & 13.0 & \\
\hline & & \multicolumn{11}{|c|}{ Average ice accretion rates $(\mathrm{mm} / \mathrm{hr})$} & \multirow{4}{*}{3.3} \\
\hline & 0.3 & 0.3 & 0.5 & 1.0 & 2.0 & 4.1 & 5.3 & 6.1 & 1.8 & 1.0 & 0.8 & & \\
\hline & 0.6 & 0.0 & 0.0 & 0.5 & 3.8 & 9.4 & 10.7 & 10.9 & 7.1 & 3.1 & 0.3 & & \\
\hline & 0.9 & 0.0 & 0.0 & 0.3 & 1.3 & 4.8 & 10.7 & 10.4 & 4.3 & 0.0 & 0.0 & & \\
\hline
\end{tabular}
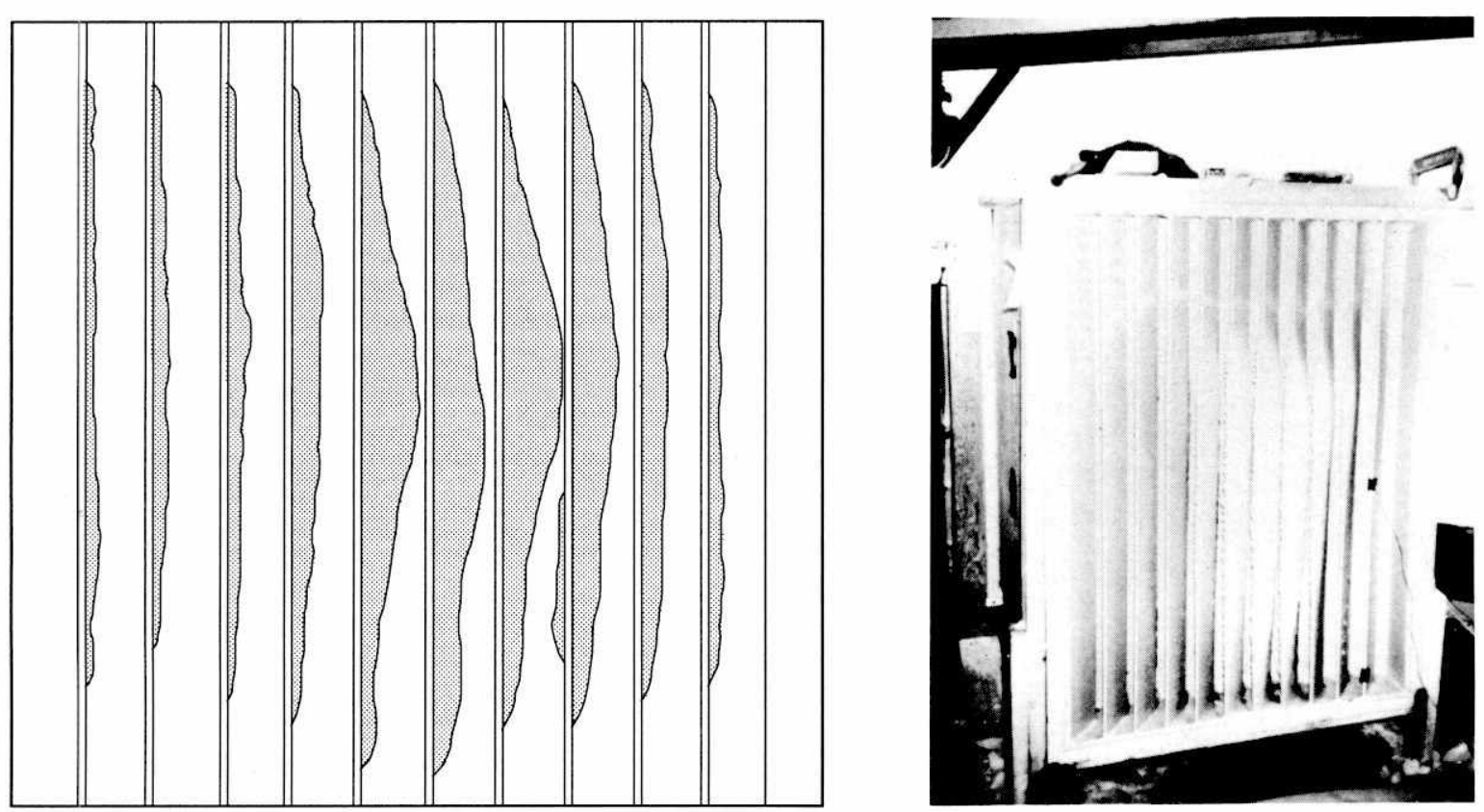

Figure C13. Icing of prototype louver at the end of test 205. 
Table C14. Ice thickness in test 206.

\begin{tabular}{|c|c|c|c|c|c|c|c|c|c|c|c|c|c|}
\hline \multirow{2}{*}{$\begin{array}{c}\text { Elapsed } \\
\text { time } \\
\text { (hours) }\end{array}$} & \multirow{2}{*}{$\begin{array}{l}\text { Dist. from } \\
\text { louver top } \\
(m)\end{array}$} & \multicolumn{11}{|c|}{ Ice thickness ( $\mathrm{mm}$ ) } & \multirow{2}{*}{$\begin{array}{c}\text { Average } \\
\text { accretion rate } \\
(\mathrm{mm} / \mathrm{hr})\end{array}$} \\
\hline & & Vane 1 & 2 & 3 & 4 & 5 & 6 & 7 & 8 & 9 & 10 & Average & \\
\hline \multirow[t]{3}{*}{1} & 0.3 & 3 & 7 & 12 & 15 & 17 & 17 & 16 & 16 & 16 & 11 & 12.7 & 11.9 \\
\hline & 0.6 & $<1$ & 1 & 3 & 11 & 17 & 18 & 20 & 32 & 21 & 9 & 13.0 & \\
\hline & 0.9 & 1 & 1 & 1 & 5 & 18 & 24 & 24 & 22 & 5 & $<1$ & 9.9 & \\
\hline \multirow[t]{3}{*}{2} & 0.3 & 5 & 13 & 23 & 30 & 30 & 36 & 28 & 27 & 34 & 32 & 25.7 & 9.4 \\
\hline & 0.6 & $<1$ & 1 & 3 & 23 & 29 & 34 & 44 & 41 & 26 & 20 & 22.1 & \\
\hline & 0.9 & $<1$ & $<1$ & $<1$ & 12 & 26 & 35 & 32 & 31 & 19 & $<1$ & 15.7 & \\
\hline \multirow[t]{3}{*}{3} & 0.3 & 9 & 22 & 33 & 40 & 43 & 76 & 36 & 76 & 76 & 76 & 48.8 & 12.2 \\
\hline & 0.6 & 2 & 3 & 8 & 37 & 42 & 56 & 54 & 43 & 34 & 23 & 30.2 & \\
\hline & 0.9 & 1 & 2 & 2 & 23 & 35 & 43 & 42 & 34 & 28 & 2 & 21.1 & \\
\hline \multirow[t]{7}{*}{4} & 0.3 & 14 & 32 & 48 & 59 & 76 & 76 & 76 & 76 & 76 & 76 & 61.0 & 11.7 \\
\hline & 0.6 & 3 & 5 & 20 & 46 & 49 & 76 & 76 & 76 & 76 & 30 & 45.7 & \\
\hline & 0.9 & 1 & 1 & 16 & 35 & 52 & 55 & 49 & 42 & 33 & $<1$ & 28.7 & \\
\hline & & \multicolumn{11}{|c|}{ Average ice accretion rates $(\mathrm{mm} / \mathrm{hr})$} & \\
\hline & 0.3 & 3.3 & 7.9 & 11.9 & 14.7 & 19.0 & 19.0 & 19.0 & 19.0 & 19.0 & 19.0 & & \\
\hline & 0.6 & 0.8 & 1.3 & 5.1 & 11.4 & 12.4 & 19.0 & 19.0 & 19.0 & 19.0 & 7.6 & & \\
\hline & 0.9 & 0.3 & 0.3 & 4.1 & 8.6 & 13.0 & 13.7 & 12.2 & 10.4 & 8.1 & 0.8 & & 11.2 \\
\hline
\end{tabular}
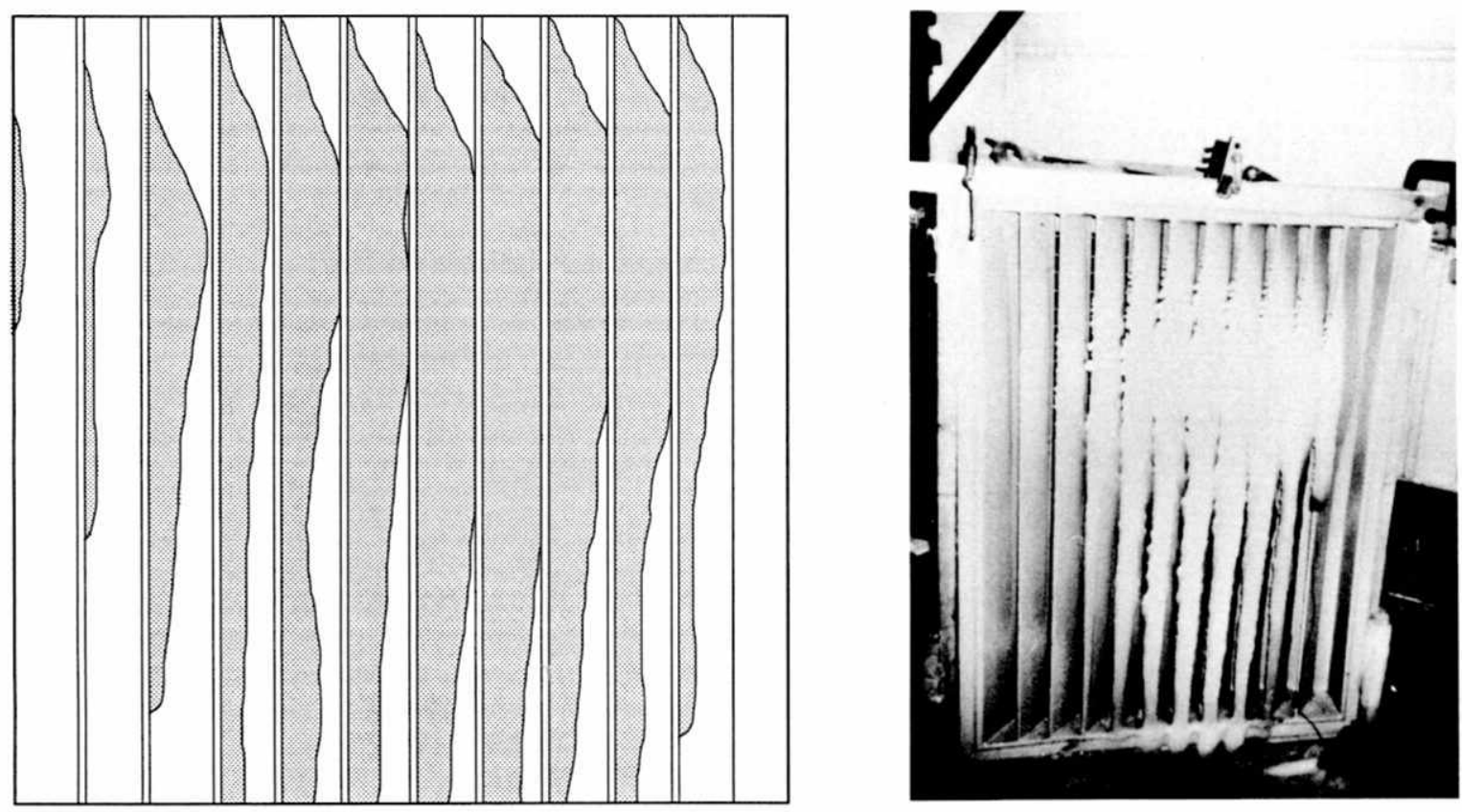

Figure C14. Icing of prototype louver at the end of test 206. 
Table C15. Ice thickness in test 207.

\begin{tabular}{|c|c|c|c|c|c|c|c|c|c|c|c|c|c|}
\hline \multirow{2}{*}{$\begin{array}{c}\text { Elapsed } \\
\text { time } \\
\text { (hours) }\end{array}$} & \multirow{2}{*}{$\begin{array}{l}\text { Dist. from } \\
\text { louver top } \\
(m)\end{array}$} & \multicolumn{11}{|c|}{ Ice thickness $(\mathrm{mm})$} & \multirow{2}{*}{$\begin{array}{c}\text { Average } \\
\text { accretion rate } \\
(\mathrm{mm} / \mathrm{hr})\end{array}$} \\
\hline & & Vane 1 & 2 & 3 & 4 & 5 & 6 & 7 & 8 & 9 & 10 & Average & \\
\hline \multirow[t]{3}{*}{1} & 0.3 & $<1$ & $<1$ & $<1$ & 1 & 2 & 3 & 2 & 1 & $<1$ & $<1$ & 1.0 & 2.8 \\
\hline & 0.6 & $<1$ & 2 & $<1$ & 10 & 9 & 8 & 8 & 5 & 2 & $<1$ & 4.8 & \\
\hline & 0.9 & $<1$ & 2 & 3 & 3 & 4 & 4 & 6 & 4 & 1 & $<1$ & 2.5 & \\
\hline \multirow[t]{3}{*}{2} & 0.3 & $<1$ & $<1$ & 1 & 2 & 4 & 5 & 4 & 3 & 1 & $<1$ & 2.0 & 2.3 \\
\hline & 0.6 & $<1$ & 3 & 89 & 15 & 15 & 14 & 15 & 10 & 4 & $<1$ & 8.6 & \\
\hline & 0.9 & 1 & 3 & 4 & 5 & 5 & 8 & 11 & 8 & 3 & 1 & 4.8 & \\
\hline \multirow[t]{3}{*}{3} & 0.3 & $<1$ & $<1$ & 1 & 3 & 9 & 11 & 9 & 6 & 2 & $<1$ & 4.1 & 3.3 \\
\hline & 0.6 & 1 & 5 & 13 & 20 & 22 & 21 & 23 & 18 & 7 & 1 & 13.2 & \\
\hline & 0.9 & 1 & 3 & 5 & 7 & 8 & 12 & 20 & 15 & 5 & 2 & 7.9 & \\
\hline \multirow[t]{7}{*}{4} & 0.3 & $<1$ & $<1$ & 2 & 6 & 11 & 15 & 15 & 10 & 4 & $<1$ & 6.4 & 3.1 \\
\hline & 0.6 & 1 & 6 & 16 & 25 & 27 & 27 & 31 & 26 & 13 & 2 & 17.3 & \\
\hline & 0.9 & 2 & 4 & 6 & 8 & 9 & 16 & 29 & 23 & 8 & 2 & 10.4 & \\
\hline & & \multicolumn{11}{|c|}{ Average ice accretion rates $(\mathrm{mm} / \mathrm{hr})$} & \\
\hline & 0.3 & 0.0 & 0.0 & 0.5 & 1.5 & 2.8 & 3.8 & 3.8 & 2.5 & 1.0 & 0.3 & & \\
\hline & 0.6 & 0.3 & 1.5 & 3.8 & 6.4 & 6.6 & 6.9 & 7.9 & 6.4 & 3.3 & 0.5 & & \\
\hline & 0.9 & 0.3 & 1.0 & 1.5 & 1.8 & 2.3 & 3.8 & 7.4 & 5.6 & 2.0 & 0.3 & & 2.8 \\
\hline
\end{tabular}
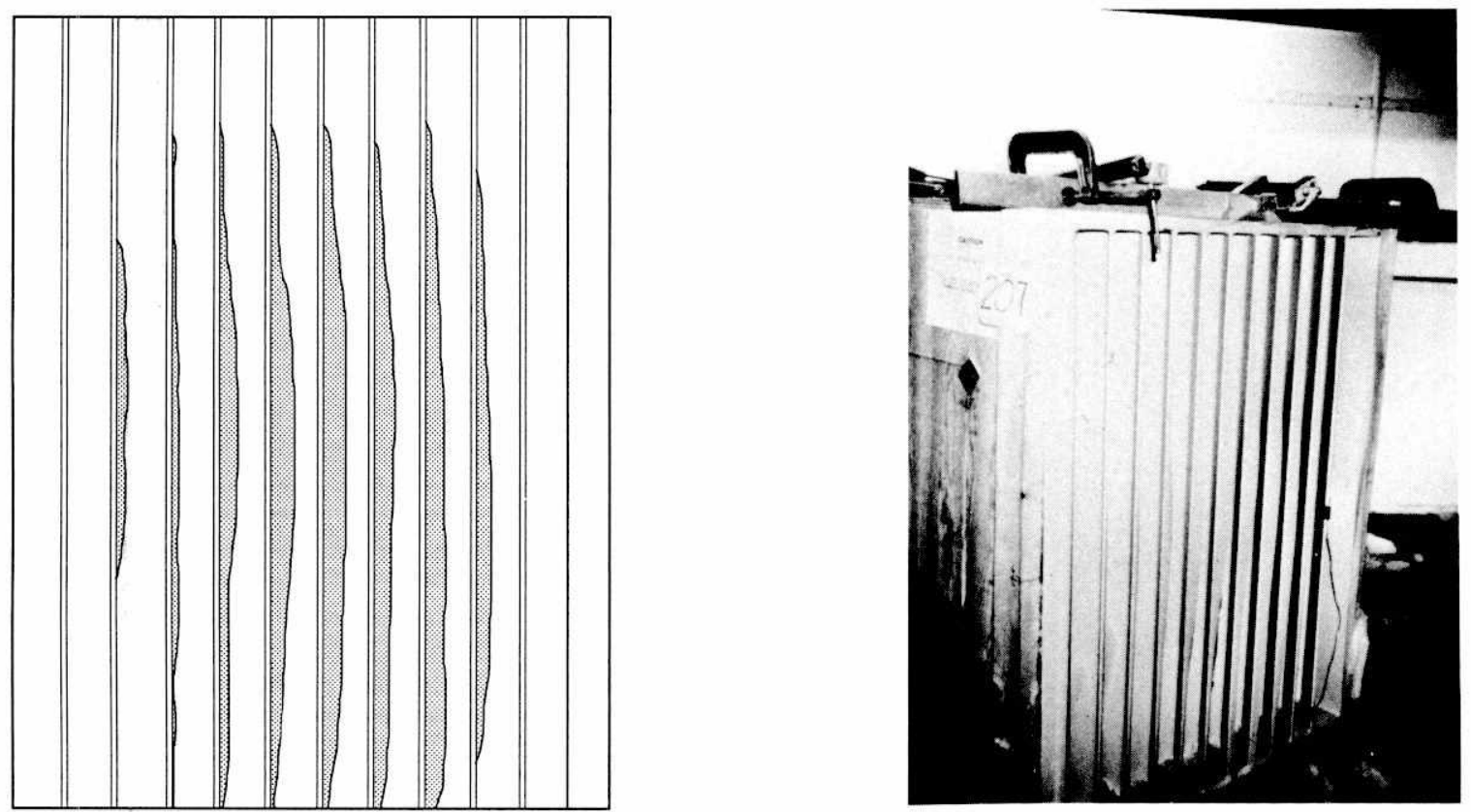

Figure C15. Icing of prototype louver at the end of test 207. 
Table C16. Ice thickness in test 208.

\begin{tabular}{|c|c|c|c|c|c|c|c|c|c|c|c|c|c|}
\hline \multirow{2}{*}{$\begin{array}{c}\text { Elapsed } \\
\text { time } \\
\text { (hours) }\end{array}$} & \multirow{2}{*}{$\begin{array}{c}\text { Dist. from } \\
\text { louver top } \\
\text { (m) }\end{array}$} & \multicolumn{11}{|c|}{ Ice thickness $(\mathrm{mm})$} & \multirow{2}{*}{$\begin{array}{c}\text { Average } \\
\text { accretion rate } \\
(\mathrm{mm} / \mathrm{hr})\end{array}$} \\
\hline & & Vane 1 & 2 & 3 & 4 & 5 & 6 & 7 & 8 & 9 & 10 & Average & \\
\hline \multirow[t]{3}{*}{1} & 0.3 & 17 & 24 & 33 & 30 & 35 & 31 & 29 & 30 & 32 & 21 & 27.9 & 25.7 \\
\hline & 0.6 & 1 & 6 & 19 & 21 & 32 & 37 & 37 & 35 & 26 & 8 & 22.1 & \\
\hline & 0.9 & 31 & 34 & 24 & 26 & 33 & 33 & 27 & 29 & 22 & 13 & 26.9 & \\
\hline \multirow[t]{7}{*}{2} & 0.3 & 22 & 31 & 57 & 76 & 76 & 76 & 76 & 76 & 76 & 76 & 64.3 & 25.9 \\
\hline & 0.6 & 2 & 17 & 42 & 48 & 54 & 47 & 56 & 76 & 76 & 76 & 49.3 & \\
\hline & 0.9 & 32 & 41 & 52 & 46 & 43 & 48 & 45 & 51 & 34 & 23 & 41.1 & \\
\hline & & \multicolumn{11}{|c|}{ Average ice accretion rates $(\mathrm{mm} / \mathrm{hr})$} & \\
\hline & 0.3 & 10.9 & 15.2 & 28.2 & 38.1 & 38.1 & 38.1 & 38.1 & 38.1 & 38.1 & 38.1 & & \\
\hline & 0.6 & 1.0 & 8.4 & 20.8 & 23.9 & 26.9 & 23.4 & 28.2 & 38.1 & 38.1 & 38.1 & & \\
\hline & 0.9 & 16.0 & 20.3 & 25.9 & 22.6 & 21.3 & 23.9 & 22.6 & 25.4 & 16.8 & 11.4 & & 25.9 \\
\hline
\end{tabular}
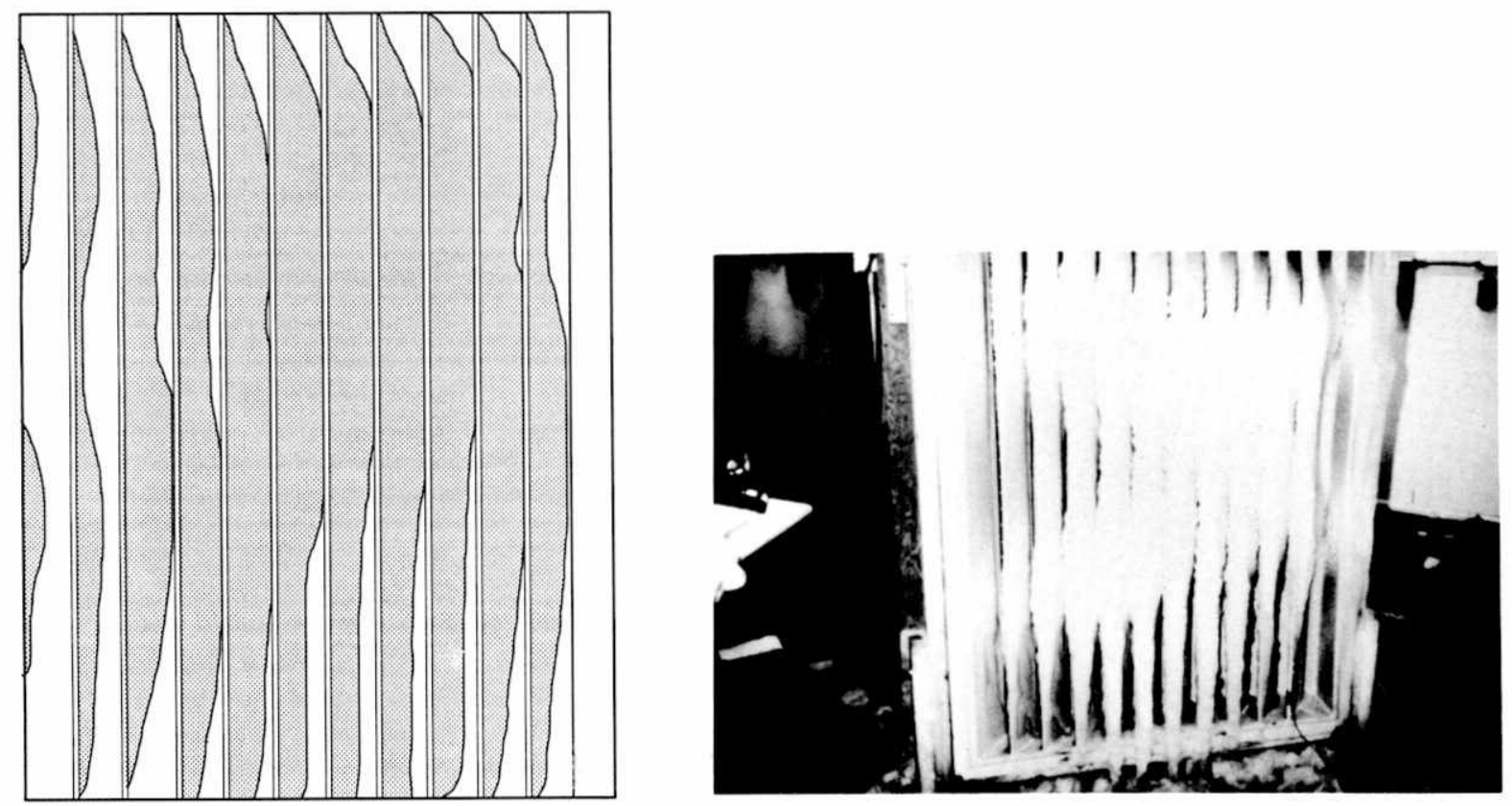

Figure C16. Icing of prototype louver at the end of test 208. 


\section{APPENDIX D: ANALYSIS OF LOUVER ICE SAMPLES FOR DENSITY}

This appendix describes the methods used in preparation, measurement and analysis of the ice samples collected from the vanes at the conclusion of each test. Table D1 contains the data obtained to derive the measured density for each sample.

From each of the raw samples obtained after the conclusion of a test, a regularly shaped piece was cut using a bandsaw. These smaller pieces ranged widely in size but were ideally from 150 to $250 \mathrm{~g}$. The length and width were maximized for the size of the weighing pan, but the sample weight varied according to thickness. When samples were so thin as to weigh less than $100 \mathrm{~g}$ as a single piece, two pieces were analyzed simultaneously if there was enough raw sample to draw from. This was to reduce the relative weighing error since an electronic balance that read to the nearest $0.1 \mathrm{~g}$ was used. These subsamples were then separately bagged, labeled and stored until the density measurements could be performed.

Due to the irregular shape and surface roughness of the spray ice accretions, an immersion technique was chosen for measuring the ice density. A sample was first weighed in air and then weighed in a fluid with a known density. Assuming the ice, air and liquid are all at the same temperature, the following equation is used to calculate the density of the ice $D_{\mathrm{i}}$ :

$$
D_{\mathrm{i}}=\left(D_{1} \cdot w_{\mathrm{a}}\right) /\left(w_{\mathrm{a}}-w_{1}\right)
$$

where $D_{1}=$ density of the liquid $\left(\mathrm{g} / \mathrm{cm}^{3}\right)$

$w_{\mathrm{a}}=$ weight of the ice in air $(\mathrm{g})$

$w_{1}=$ weight of the ice in liquid (g).

All weighings were done in a coldroom with the fans turned off to eliminate error caused by air turbulence. Since the salineice was soft, each sample was placed on a disposable sheet so that fragments would not be lost between the times of weighing in air and weighing in the liquid. Squares of aluminum foil measuring $13 \times 13 \mathrm{~cm}$ were cut and used for this purpose. Each of the sample weighings therefore includes the mass of its foil sheet. For the weight measurements in air, the balance was tared to exclude the weight of the weighing pan, but the weights in liquid must be reduced to account for the buoyant force on the pan. With these experimental conditions the modified form of eq D1 shown below is used for calculating ice density:

$$
\begin{array}{r}
D_{\mathrm{i}}=\left(D_{\mathrm{l}} \cdot w_{\mathrm{a}}\right) /\left[\left(w_{\mathrm{a}}-f_{\mathrm{a}}\right)\right. \\
\left.-\left(w_{1}-f_{1}\right)-\left(p_{\mathrm{a}}-p_{1}\right)\right]
\end{array}
$$

where $w_{\mathrm{a}}=$ weight of the sample and foil in air

$f_{\mathrm{a}}=$ weight of the foil in air

$w_{1}=$ weight of the sample, foil and weighing pan in liquid

$f_{1}=$ weight of the foil in liquid

$p_{\mathrm{a}}=$ weight of the weighing pan in air

$p_{1}=$ weight of the weighing pan in liquid.

The preferred liquid for finding the density of ice is water-saturated 2,2,4 trimethylpentane, also known as isooctane. Water (and ice) are highly insoluble in it. Its melting point is $-107.4^{\circ} \mathrm{C}$, and it is less dense than ice so that the ice can be submerged in it. Because it is highly volatile and evaporates quickly, it is also not as messy as other fluids (such as kerosene), which are sometimes used.

Initial weighings used heavy-duty aluminum foil, but after the supply of this material ran out, analysis was completed using a lighter foil. A sampling of eight sheets of the heavy duty foil showed each to have a weight in air of $1.1 \mathrm{~g}$. Each sheet of a similar sampling of the lighter foil weighed $0.7 \mathrm{~g}$ in air. The foil sheets were found to weigh 0.7 and 0.5 $\mathrm{g}$ in the isooctane.

Twelve ice samples were processed at a time in the following manner. A 1000-mL graduated cylinder was filled with isooctane and placed on the benchtop. A mercury thermometer with $0.1^{\circ} \mathrm{C}$ graduations and a hygrometer with $0.0005-\mathrm{g} / \mathrm{cm}^{3}$ graduations were placed in the isooctane. A 3-L Plexiglas container two-thirds filled with the liquid was situated on the floor directly beneath the balance. The 12 samples were weighed consecutively in air on the tared balance (Sartorius Model B4100), each on its respective foil sheet. The balance was retared between weighings if the display did not return exactly to $0.0 \mathrm{~g}$. After the 12 weighings in air were completed, the air temperature (to the nearest $0.10^{\circ} \mathrm{C}$ ) was recorded from a digital thermometer (Omega Model 866), and the liquid's temperature and density were recorded.

A hole in the benchtop allowed a pan to be suspended from a weighing hook on the underside of the balance. Two wire hooks of different lengths were hung from the balance's hook. The shorter wire held the pan above the liquid, while the longer one suspended the pan in the liquid. An initial weighing of the pan hanging in air was $122.5 \mathrm{~g}$ on the first day and $122.6 \mathrm{~g}$ on the second. A piece of white thread was tied to the one suspension arm of the pan to mark its immersion level in the fluid. After the pan was moved onto the longer hook, which lowered it into the fluid, a pneumatic pump 
and tubing were used to withdraw or replace fluid to the immersion level marked by the thread. This ensured that the weighing pan was always submerged to the same level and hence that the buoyant force acting upon it was constant. The weight of the pan in the fluid was found to be $115.8 \mathrm{~g}$. With the pan dry and on the shorter wire hook, the balance was tared before a sample was placed on the pan. The pan was lowered into the fluid on the long wire hook, and the fluid level was checked by sighting through the clear Plexiglas sides of the container. The fluid level was brought to the immersion mark by either withdrawal or addition, and the resulting mass was recorded.

The pan was then lifted out of the liquid and hung from the short hook for the sample to drain. The sample and its foil were then discarded, and a new sample was placed on the pan. The balance no longer returned to zero due to the weight of the liquid now on the pan from the previous weighing (exterior surface wetting). To verify the balance, the tare level was checked when the pan with the new sample was lifted for placing onto the longer hook. With the pan off the hook, the balance should have read $-122.5 \mathrm{~g}$.

After the above measurements were obtained for the group of 12 samples, the air and liquid temperatures and the liquid's density were again recorded. Typically the time elapsed between the beginning and ending sets of readings was 15-20 minutes, and the fluid density readings never varied more than $0.0011 \mathrm{~g} / \mathrm{cm}^{3}$. Nonetheless, each calculated sample density uses an interpolated fluid density, assuming that each weighing took the same amount of time to perform. The isooctane from both the immersion tub and the graduated cylinder was then emptied back into a storage container to remix for the next set of samples. Table D1 contains the data obtained to derive the measured density for each sample.

Table D1. Navy louver icing density data (see eq D2).

\begin{tabular}{|c|c|c|c|c|c|c|c|c|c|c|c|c|}
\hline $\begin{array}{l}\text { Sample } \\
\text { number }\end{array}$ & $\begin{array}{l}\text { Test } \\
\text { date }\end{array}$ & $\begin{array}{c}D_{l} \\
\left(\mathrm{~g} / \mathrm{cm}^{3}\right)\end{array}$ & $\begin{array}{l}\mathrm{w}_{a} \\
(\mathrm{~g})\end{array}$ & $\begin{array}{l}\mathbf{w}_{l} \\
(g)\end{array}$ & $\begin{array}{c}\mathrm{f}_{a} \\
(g)\end{array}$ & $\begin{array}{c}f_{1} \\
(g)\end{array}$ & $\begin{array}{l}\mathrm{Pa}_{a} \\
(\mathrm{~g})\end{array}$ & $\begin{array}{l}\mathrm{Pl}_{1} \\
(\mathrm{~g})\end{array}$ & $\begin{array}{l}\text { Density } \\
\left(\mathrm{g} / \mathrm{cm}^{3}\right)\end{array}$ & $\begin{array}{c}\text { Mean } \\
\left(\mathrm{g} / \mathrm{cm}^{3}\right)\end{array}$ & $\begin{array}{l}\text { St. Dev. } \\
\left(\mathrm{g} / \mathrm{cm}^{3}\right)\end{array}$ & $\begin{array}{l}\text { Range } \\
\left(\mathrm{g} / \mathrm{cm}^{3}\right)\end{array}$ \\
\hline 101-L1 & 503 & 0.7197 & 178.2 & 27.6 & 1.1 & 0.7 & 122.5 & 115.8 & 0.8882 & & & \\
\hline 101-L2 & 503 & 0.7197 & 180.9 & 26.0 & 1.1 & 0.7 & 122.5 & 115.8 & 0.8755 & & & \\
\hline 101-L3 & 503 & 0.7197 & 210.7 & 32.0 & 1.1 & 0.7 & 122.5 & 115.8 & 0.8791 & & & \\
\hline 101-L4 & 503 & 0.7163 & 216.6 & 34.3 & 1.1 & 0.7 & 122.5 & 115.8 & 0.8811 & & & \\
\hline 101-L5 & 503 & 0.7197 & 121.8 & 19.8 & 1.1 & 0.7 & 122.5 & 115.8 & 0.9154 & 0.888 & 0.014 & 0.040 \\
\hline 102-L1 & 503 & 0.7198 & 257.1 & 49.8 & 0.7 & 0.5 & 122.6 & 115.8 & 0.9214 & & & \\
\hline 102-L2 & 503 & 0.7195 & 191.6 & 31.1 & 0.7 & 0.5 & 122.6 & 115.8 & 0.8948 & & & \\
\hline 102-L3 & 503 & 0.7193 & 200.4 & 32.8 & 0.7 & 0.5 & 122.6 & 115.8 & 0.8944 & & & \\
\hline 102-L4 & 503 & 0.7186 & 239.2 & 38.6 & 0.7 & 0.5 & 122.6 & 115.8 & 0.8853 & & & \\
\hline 102-L5 & 503 & 0.7195 & 237.7 & 40.7 & 0.7 & 0.5 & 122.6 & 115.8 & 0.8975 & 0.899 & 0.012 & 0.036 \\
\hline 103-L1 & 504 & 0.7174 & 140.5 & 18.0 & 1.1 & 0.7 & 122.5 & 115.8 & 0.8666 & & & \\
\hline 103-L2 & 504 & 0.7175 & 114.6 & 14.9 & 1.1 & 0.7 & 122.5 & 115.8 & 0.8795 & & & \\
\hline 103-L3 & 504 & 0.7177 & 151.1 & 18.8 & 1.1 & 0.7 & 122.5 & 115.8 & 0.8599 & & & \\
\hline 103-L4 & 504 & 0.7178 & 112.5 & 12.9 & 1.1 & 0.7 & 122.5 & 115.8 & 0.8645 & & & \\
\hline 103-L5 & 504 & 0.7197 & 36.1 & 0.6 & 1.1 & 0.7 & 122.5 & 115.8 & 0.8870 & 0.871 & 0.010 & 0.027 \\
\hline 104-L1 & 505 & 0.7182 & 229.9 & 32.6 & 1.1 & 0.7 & 122.5 & 115.8 & 0.8640 & & & \\
\hline 104-L2 & 505 & 0.7182 & 165.1 & 21.4 & 1.1 & 0.7 & 122.5 & 115.8 & 0.8623 & & & \\
\hline 104-L3 & 505 & 0.7197 & 183.4 & 23.8 & 1.1 & 0.7 & 122.5 & 115.8 & 0.8603 & & & \\
\hline 104-L4 & 505 & 0.7208 & 190.7 & 26.6 & 1.1 & 0.7 & 122.5 & 115.8 & 0.8705 & & & \\
\hline 104-L5 & 505 & 0.7197 & 172.0 & 22.8 & 1.1 & 0.7 & 122.5 & 115.8 & 0.8656 & 0.865 & 0.003 & 0.010 \\
\hline 105-L2T & 505 & 0.7182 & 210.7 & 37.9 & 1.1 & 0.7 & 122.5 & 115.8 & 0.9085 & & & \\
\hline 105-L3B & 505 & 0.7182 & 173.0 & 26.5 & 1.1 & 0.7 & 122.5 & 115.8 & 0.8856 & & & \\
\hline 105-L3T & 505 & 0.7182 & 155.8 & 24.1 & 1.1 & 0.7 & 122.5 & 115.8 & 0.8917 & & & \\
\hline 105-L4B & 505 & 0.7197 & 92.7 & 12.3 & 1.1 & 0.7 & 122.5 & 115.8 & 0.8994 & & & \\
\hline 105-L4T & 505 & 0.7182 & 106.5 & 14.2 & 1.1 & 0.7 & 122.5 & 115.8 & 0.8885 & 0.895 & 0.008 & 0.023 \\
\hline 106-L1 & 506 & 0.7182 & 129.1 & 15.9 & 1.1 & 0.7 & 122.5 & 115.8 & 0.8664 & & & \\
\hline 106-L2 & 506 & 0.7182 & 206.3 & 31.2 & 1.1 & 0.7 & 122.5 & 115.8 & 0.8772 & & & \\
\hline 106-L3 & 506 & 0.7182 & 147.6 & 19.7 & 1.1 & 0.7 & 122.5 & 115.8 & 0.8710 & & & \\
\hline 106-L4 & 506 & 0.7182 & 170.3 & 19.4 & 1.1 & 0.7 & 122.5 & 115.8 & 0.8451 & & & \\
\hline 106-L5 & 506 & 0.7182 & 109.4 & 13.0 & 1.1 & 0.7 & 122.5 & 115.8 & 0.8710 & 0.866 & 0.011 & 0.032 \\
\hline
\end{tabular}


Table D1 (cont'd).

\begin{tabular}{|c|c|c|c|c|c|c|c|c|c|c|c|c|}
\hline $\begin{array}{l}\text { Sample } \\
\text { number }\end{array}$ & $\begin{array}{l}\text { Test } \\
\text { Date }\end{array}$ & $\begin{array}{c}\mathrm{D}_{\mathrm{l}} \\
\left(\mathrm{g} / \mathrm{cm}^{3}\right)\end{array}$ & $\begin{array}{l}\mathbf{w}_{a} \\
(g)\end{array}$ & $\begin{array}{l}\mathrm{w}_{l} \\
(\mathrm{~g})\end{array}$ & $\begin{array}{c}\mathrm{f}_{a} \\
(\mathrm{~g})\end{array}$ & $\begin{array}{c}f_{1} \\
(g)\end{array}$ & $\begin{array}{l}\mathrm{P}_{a} \\
(\mathrm{~g})\end{array}$ & $\begin{array}{l}\mathrm{Pl} \\
(\mathrm{g})\end{array}$ & $\begin{array}{l}\text { Density } \\
\left(\mathrm{g} / \mathrm{cm}^{3}\right)\end{array}$ & $\begin{array}{l}\text { Mean } \\
\left(\mathrm{g} / \mathrm{cm}^{3}\right)\end{array}$ & $\begin{array}{l}\text { St. Dev. } \\
\left(\mathrm{g} / \mathrm{cm}^{3}\right)\end{array}$ & $\begin{array}{l}\text { Range } \\
\left(\mathrm{g} / \mathrm{cm}^{3}\right)\end{array}$ \\
\hline 107-L1 & 506 & 0.7180 & 203.8 & 31.3 & 1.1 & 0.7 & 122.5 & 115.8 & 0.8799 & & & \\
\hline 107-L2 & 506 & 0.7180 & 131.8 & 15.2 & 1.1 & 0.7 & 122.5 & 115.8 & 0.8570 & & & \\
\hline 107-L3 & 506 & 0.7200 & 136.4 & 18.3 & 0.7 & 0.5 & 122.6 & 115.8 & 0.8794 & & & \\
\hline 107-L4 & 506 & 0.7180 & 103.4 & 11.6 & 1.1 & 0.7 & 122.5 & 115.8 & 0.8672 & & & \\
\hline 107-L5 & 506 & 0.7180 & 129.9 & 19.6 & 1.1 & 0.7 & 122.5 & 115.8 & 0.8961 & 0.876 & 0.013 & 0.039 \\
\hline 108-L1 & 506 & 0.7205 & 240.5 & 42.2 & 0.7 & 0.5 & 122.6 & 115.8 & 0.9032 & & & \\
\hline 108-L2 & 506 & 0.7198 & 199.7 & 34.4 & 0.7 & 0.5 & 122.6 & 115.8 & 0.9049 & & & \\
\hline 108-L3 & 506 & 0.7194 & 251.3 & 40.0 & 0.7 & 0.5 & 122.6 & 115.8 & 0.8824 & & & \\
\hline 108-L4 & 506 & 0.7204 & 267.2 & 40.1 & 0.7 & 0.5 & 122.6 & 115.8 & 0.8723 & & & \\
\hline 108-L5 & 506 & 0.7199 & 183.8 & 33.7 & 0.7 & 0.5 & 122.6 & 115.8 & 0.9211 & 0.897 & 0.017 & 0.049 \\
\hline 201-L1 & 504 & 0.7197 & 102.0 & 13.1 & 1.1 & 0.7 & 122.5 & 115.8 & 0.8877 & & & \\
\hline 201-L3 & 504 & 0.7197 & 206.1 & 32.1 & 1.1 & 0.7 & 122.5 & 115.8 & 0.8840 & & & \\
\hline 201-L5 & 504 & 0.7168 & 171.4 & 24.6 & 1.1 & 0.7 & 122.5 & 115.8 & 0.8738 & & & \\
\hline 201-L7 & 504 & 0.7166 & 199 & 32.7 & 1.1 & 0.7 & 122.5 & 115.8 & 0.8908 & & & \\
\hline 201-L9 & 504 & 0.7201 & 125.7 & 21.0 & 0.7 & 0.5 & 122.6 & 115.8 & 0.9213 & 0.892 & 0.016 & 0.048 \\
\hline 202-L4 & 503 & 0.7191 & 125.6 & 18.1 & 0.7 & 0.5 & 122.6 & 115.8 & 0.8937 & & & \\
\hline 202-L6 & 503 & 0.7187 & 179.4 & 26.4 & 0.7 & 0.5 & 122.6 & 115.8 & 0.8797 & & & \\
\hline 202-L8 & 503 & 0.7190 & 137.4 & 21.5 & 0.7 & 0.5 & 122.6 & 115.8 & 0.9025 & 0.882 & 0.019 & 0.055 \\
\hline 203-L1 & 504 & 0.7155 & 77.0 & 5.8 & 1.1 & 0.7 & 122.5 & 115.8 & 0.8472 & & & \\
\hline 203-L3 & 504 & 0.7154 & 137.7 & 20.1 & 1.1 & 0.7 & 122.5 & 115.8 & 0.8843 & & & \\
\hline 203-L5 & 504 & 0.7197 & 134.9 & 21.1 & 1.1 & 0.7 & 122.5 & 115.8 & 0.9025 & & & \\
\hline 203-L7 & 504 & 0.7188 & 141.4 & 18.9 & 0.7 & 0.5 & 122.6 & 115.8 & 0.8756 & & & \\
\hline 203-L9 & 504 & 0.7197 & 75.5 & 7.6 & 1.1 & 0.7 & 122.5 & 115.8 & 0.8807 & 0.878 & 0.018 & 0.055 \\
\hline 204-L1 & 504 & 0.7180 & 144.6 & 20.8 & 1.1 & 0.7 & 122.5 & 115.8 & 0.8829 & & & \\
\hline 204-L3 & 504 & 0.7180 & 131.2 & 15.3 & 1.1 & 0.7 & 122.5 & 115.8 & 0.8586 & & & \\
\hline 204-L5 & 504 & 0.7180 & 115.4 & 13.1 & 1.1 & 0.7 & 122.5 & 115.8 & 0.8621 & & & \\
\hline 204-L7 & 504 & 0.7180 & 120.7 & 14.6 & 1.1 & 0.7 & 122.5 & 115.8 & 0.8674 & & & \\
\hline 204-L9 & 504 & 0.7180 & 144.9 & 19.1 & 1.1 & 0.7 & 122.5 & 115.8 & 0.8698 & 0.868 & 0.008 & 0.024 \\
\hline 205-L5T & 505 & 0.7140 & 196.6 & 34.0 & 1.1 & 0.7 & 122.5 & 115.8 & 0.8976 & & & \\
\hline 205-L6B & 505 & 0.7202 & 225.7 & 36.0 & 0.7 & 0.5 & 122.6 & 115.8 & 0.8869 & & & \\
\hline 205-L6T & 505 & 0.7203 & 249.2 & 42.6 & 0.7 & 0.5 & 122.6 & 115.8 & 0.8968 & & & \\
\hline 205-L7B & 505 & 0.7197 & 189.3 & 32.8 & 0.7 & 0.5 & 122.6 & 115.8 & 0.9079 & & & \\
\hline 205-L8T & 505 & 0.7197 & 162.5 & 28.5 & 1.1 & 0.7 & 122.5 & 115.8 & 0.9154 & 0.901 & 0.010 & 0.028 \\
\hline 206-L1 & 507 & 0.7199 & 101.2 & 15.1 & 0.7 & 0.5 & 122.6 & 115.8 & 0.9147 & & & \\
\hline 206-L3 & 507 & 0.7199 & 343.9 & 52.2 & 0.7 & 0.5 & 122.6 & 115.8 & 0.8678 & & & \\
\hline 206-L5 & 507 & 0.7199 & 311.8 & 47.8 & 0.7 & 0.5 & 122.6 & 115.8 & 0.8714 & & & \\
\hline 206-L7 & 507 & 0.7199 & 262.6 & 45.4 & 0.7 & 0.5 & 122.6 & 115.8 & 0.8970 & & & \\
\hline 206-L9 & 507 & 0.7199 & 303.2 & 54.3 & 0.7 & 0.5 & 122.6 & 115.8 & 0.9002 & 0.890 & 0.018 & 0.047 \\
\hline 207-L3 & 507 & 0.7199 & 192.9 & 34.6 & 0.7 & 0.5 & 122.6 & 115.8 & 0.9145 & & & \\
\hline 207-L5 & 507 & 0.7184 & 274.4 & 46.7 & 0.7 & 0.5 & 122.6 & 115.8 & 0.8909 & & & \\
\hline 207-L7 & 507 & 0.7184 & 199.0 & 31.7 & 0.7 & 0.5 & 122.6 & 115.8 & 0.8887 & & & \\
\hline 207-L9 & 507 & 0.7199 & 121.9 & 20.1 & 0.7 & 0.5 & 122.6 & 115.8 & 0.9204 & 0.904 & 0.014 & 0.032 \\
\hline 208-L1 & 507 & 0.7199 & 255.3 & 47.3 & 0.7 & 0.5 & 122.6 & 115.8 & 0.9119 & & & \\
\hline 208-L3 & 507 & 0.7199 & 290.3 & 52.9 & 0.7 & 0.5 & 122.6 & 115.8 & 0.9049 & & & \\
\hline 208-L5 & 507 & 0.7199 & 258.1 & 43.4 & 0.7 & 0.5 & 122.6 & 115.8 & 0.8922 & & & \\
\hline 208-L7 & 507 & 0.7199 & 321.8 & 53.2 & 0.7 & 0.5 & 122.6 & 115.8 & 0.8836 & & & \\
\hline 208-L9 & 507 & 0.7199 & 257.3 & 45.8 & 0.7 & 0.5 & 122.6 & 115.8 & 0.9033 & 0.899 & 0.010 & 0.028 \\
\hline & & & & & & & & & $\begin{array}{l}\text { MAX = } \\
\text { MIN }=\end{array}$ & $\begin{array}{l}0.904 \\
0.865\end{array}$ & $\begin{array}{l}0.019 \\
0.003\end{array}$ & $\begin{array}{l}0.055 \\
0.010\end{array}$ \\
\hline
\end{tabular}


Public reporting burden for this collection of information is estimated to average 1 hour per response, including the time for reviewing instructions, searching existing data sources, gathering and maintaining the data needed, and completing and reviewing the collection of information. Send comments regarding this burden estimate or any other aspect of this collection of information, including suggestion for reducing this burden, to Washington Headquarters Services, Directorate for Information Operations and Reports, 1215 Jefferson Davis Highway. Suite 1204, Arlington, VA 22202-4302, and to the Office of Management and Budget, Paperwork Reduction Project (0704-0188), Washington, DC 20503.

\begin{tabular}{|l|l|l|}
\hline 1. AGENCY USE ONLY (Leave blank) & $\begin{array}{c}\text { 2. REPORT DATE } \\
\text { April } 1993\end{array}$ & 3. REPORT TYPE AND DATES COVERED \\
\hline
\end{tabular}

4. TITLE AND SUBTITLE

5. FUNDING NUMBERS

Icing of Turbine Intake Louvers

6. AUTHORS

Michael R. Walsh, Donald E. Garfield, James S. Morse, Kurt V. Knuth,

Nathan D. Mulherin and George E. Lemieux

7. PERFORMING ORGANIZATION NAME(S) AND ADDRESS(ES)

8. PERFORMING ORGANIZATION

U.S. Army Cold Regions Research and Engineering Laboratory

72 Lyme Road REPORT NUMBER

Hanover, New Hampshire 03755-1290

Special Report 93-4

9. SPONSORING/MONITORING AGENCY NAME(S) AND ADDRESS(ES)

10. SPONSORING/MONITORING

Advanced Marine Enterprises, Inc. (AME)

AGENCY REPORT NUMBER

Arlington, Virginia 22202

11. SUPPLEMENTARY NOTES

12a. DISTRIBUTION/AVAILABILITY STATEMENT 12b. DISTRIBUTION CODE

Approved for public release; distribution is unlimited.

Available from NTIS, Springfield, Virginia 22161

13. ABSTRACT (Maximum 200 words)

Superstructure icing can have debilitating effects on the operation of any ship. When designing ships that will operate in environments where icing may occur, careful consideration must be given to minimizing the accumulation and effect of shipboard icing. Such consideration was given to the Navy DDG-51 class destroyer when new turbine intake louvers were proposed. To ensure that sufficient air would be available to the vessel's gas turbines and ventilation system during an icing event, the U.S. Navy tasked the U.S. Army Cold Regions Research and Engineering Laboratory (CRREL) to conduct a series of comparative icing tests between standard intake louvers and a new louver design. Using a test matrix and design parameters supplied by a Navy contractor, CRREL designed a test apparatus and instrumentation suite to carry out the tests. Testing conducted with reconstituted seawater at the CRREL facility demonstrated that, under various icing conditions, the rate of ice accumulation of the two louver designs was very similar. However, the increased number of louver vanes of the proposed design led to more rapid restriction of air accumulation on the vanes.

\begin{tabular}{|c|c|c|}
\hline \multicolumn{3}{|l|}{ 14. SUBJECT TERMS } \\
\hline Icing & Ships & cretion rates \\
\hline $\begin{array}{l}\text { 17. SECURITY CLASSIFICATION } \\
\text { OF REPORT }\end{array}$ & $\begin{array}{l}\text { 18. SECURITY CLASSIFICATION } \\
\text { OF THIS PAGE }\end{array}$ & $\begin{array}{l}\text { 19. SECURITY CLASSIFICATION } \\
\text { OF ABSTRACT }\end{array}$ \\
\hline UNCLASSIFIED & UNCLASSIFIED & UNCLASSIFIED \\
\hline
\end{tabular}

